\title{
The syn-orogenic sedimentary record of the Grenville Orogeny in southwest Laurentia
}

\author{
Mulder $^{1}$, J. A., Karlstrom ${ }^{2}$, K. E., Fletcher ${ }^{3}$, K., Heizler ${ }^{3}$, M. T., Timmons ${ }^{3}$, J. M., Crossey ${ }^{2}$, L. J., Gehrels ${ }^{4}$, G. E., Pecha, \\ M. $^{4}$ \\ ${ }^{1}$ ARC Centre of Excellence in Ore Deposits (CODES), School of Physical Sciences, University of Tasmania, Tasmania \\ 7001, Australia. \\ ${ }^{2}$ Department of Earth and Planetary Sciences, University of New Mexico, Albuquerque, New Mexico 87106, USA \\ ${ }^{3}$ New Mexico Bureau of Geology and Mineral Resources, New Mexico Institute of Technology, Socorro, New \\ Mexico 87801, USA. \\ ${ }^{4}$ Department of Geosciences, University of Arizona, Tucson, Arizona 85721, USA.
}

\begin{abstract}
Late Mesoproterozoic sedimentary sequences in southwest Laurentia range in age from 1340 to 1035 $\mathrm{Ma}$ and record regionally extensive intracratonic sedimentation before and during the Grenville Orogeny in southern Laurentia. This paper examines the specific links between intracratonic sedimentation and orogenesis and develops a new tectonic model for basin formation throughout southwest Laurentia during the Late Mesoproterozoic. New detrital zircon, muscovite, and biotite ages refine the provenance, depositional age, and regional correlations of Late Mesoproterozoic strata throughout southwest Laurentia. These data provide a new view of the Grenville orogen in southern Laurentia as it evolved from a continental margin arc to a continent-continent collision based on the record of inboard sedimentation. Deposition of all Late Mesoproterozoic sequences in southwest Laurentia was facilitated by far-traveled, continental-scale rivers that flowed north off the developing Grenville orogen. Sediment accumulation took place during four discrete basin forming events that can be directly linked to changes in the style of convergence and collision along the southern margin of Laurentia. The oldest basin system (lower Apache and Pahrump Groups) records distal back arc basin sedimentation at 1340-1320 $\mathrm{Ma}$, synchronous with widespread magmatism along the southern margin of Laurentia. Unconformably overlying shallow marine carbonate-bearing sequences (lower Unkar Group and correlatives) were deposited between 1255 and $1230 \mathrm{Ma}$ in a regionally extensive retroarc basin with clastic sediment sourced in part from an active continental arc along the southern margin of Laurentia. Shallow marine and terrestrial siliciclastic sequences (upper Unkar Group and correlatives) were deposited at 1140$1100 \mathrm{Ma}$ and were sourced from unroofing thrust nappes in the orogen to the south in an extensive foreland basin system during continent-continent collision. Finally, coarse-grained siliciclastic deposits of the 1060-1035 Ma Hazel Formation represent a proximal foreland basin recording the final stages of the Grenville Orogeny in southern Laurentia.
\end{abstract}




\subsection{Introduction}

The Late Mesoproterozoic marks one of the most active episodes of collisional tectonics in Earth's history, culminating in the amalgamation of the supercontinent Rodinia between 1300 and $900 \mathrm{Ma}$ (Li et al., 2008). Laurentia (Proterozoic North America) occupied a central position within Rodinia and is bound on its eastern and southern margins by the Grenville orogen, which represents a key record of the assembly of the supercontinent (e.g. Tohver et al., 2006; Mosher et al., 2008; Li et al., 2008). The tectonic evolution of the northeastern segment of the Grenville Orogeny has been extensively studied from exposures in northeastern United States, eastern Canada, and formerly contiguous crust in Scotland and Ireland (e.g. Davidson, 1995; Rivers, 1997, 2008; Tollo et al., 2004; Storey et al., 2005; Daly \& Flowerdew, 2005; McLelland et al., 2010a). The timing and geodynamic significance of the Grenville Orogeny in southern Laurentia is less well understood as this portion of the orogen is only exposed in isolated basement uplifts in central and western Texas (Mosher, 1998; Bickford et al., 2000; Mosher et al., 2008).

Although outcrops of the Late Mesoproterozoic core of the Grenville orogen in southern Laurentia are aerially limited, sedimentary basins of this age are widespread throughout southwest Laurentia (Fig. 1) and are interpreted to record intracratonic sedimentation in response to collision along the southern margin of Laurentia (Seeley, 1999; Timmons et al., 2005). In these models, Late Mesoproterozoic strata have been shown to be a record of north-flowing continental-scale rivers sourced from the developing Grenville orogen with basin accommodation space driven by orogen-related intracratonic tectonism. However, the specific links between intracratonic basin formation, sedimentation, and orogenesis are incompletely understood in the context of the most recent tectonic models for the Grenville Orogeny in southern Laurentia (Carlson et al., 2007; Mosher et al., 2008; Levine \& Mosher, 2010; Davis \& Mosher, 2015).

Syn-orogenic basins are a sensitive record of the tectonic evolution of orogens as their provenance and depositional history are fundamentally linked to major tectonic events during collision (e.g. Beaumont, 1981; Sinclair, 1997; DeCelles \& Giles, 1996; Carrapa et al., 2004a, DeCelles et al., 2004, Garzanti et al., 2004, Decelles, 2012; Allen et al., 2015). This paper refines the provenance and depositional history of Late Mesoproterozoic sequences in southwest Laurentia with an extensive detrital zircon, muscovite, and biotite dataset. A detailed record of the provenance of Late Mesoproterozoic sequences in southwest Laurentia is achieved by integrating detrital zircon and mica datasets so that both the crystallization ages of rocks in the source region and the time at which metamorphic rocks cooled through the mica closure temperatures $\left(300-350^{\circ} \mathrm{C}\right)$ during exhumation are recorded The goal is to further understand the relationship between intracratonic sedimentation and Late Mesoproterozoic orogenesis in southern Laurentia. This leads to a new tectonic model for Late Mesoproterozoic sedimentation in southwest Laurentia and a refined model for the southern Grenville orogen as it evolved from a continental margin arc to a continent-continent collision from ca. 1350 to $1000 \mathrm{Ma}$. 


\subsection{Geological Setting}

During the Paleoproterozoic and Mesoproterozoic Laurentia was constructed by the progressive addition of dominantly juvenile crust to the Archean cratonic core of the Canadian shield by a series of southward-younging orogenic events (Karlstrom \& Bowring, 1988; Hoffman, 1988; Whitmeyer \& Karlstrom, 2007). Paleoproterozoic orogenic events in southwest Laurentia involved the accretion of 1800-1700 Ma island arc crust of the Yavapai province (e.g. Holland et al., 2015; Link et al., 2016) and emplacement and deformation of 1680-1600 Ma continental margin arc and back arc assemblages defining the Mazatzal province (Fig. 1, Karlstrom \& Bowring, 1988, 1993; Wooden et al., 1988; Williams, 1991; Whitmeyer \& Karlstrom, 2007; Duebendorfer, 2015). Sedimentation was closely associated with crust formation in the Yavapai and Mazatzal provinces. Most Paleoproterozoic basins were derived from a combination of newly accreted crust, post-collisional magmatic rocks, and recycling of older basement rocks (Jones et al., 2009, 2011, 2015; Shufeldt et al. 2010; Doe et al., 2012; 2013; Daniel et al., 2013; Holland et al., 2015). Following tectonic quiescence during the 1610-1490 Ma North American Magmatic Gap (Bowring \& Karlstrom, 1990; Ross \& Villeneuve, 2003; Karlstrom et al., 2004), accretion continued in southwest Laurentia with the docking of 1550-1400 Ma juvenile crust (Whitmeyer \& Karlstrom, 2007). Accretion was accompanied by widespread 1480-1350 Ma A-type magmatism that defines the Granite-Rhyolite Province in southeastern Laurentia (Van Schmus et al., 1996; Whitmeyer \& Karlstrom, 2007; Bickford et al., 2015) and also extends into the inboard Paleoproterozoic basement terranes of southwest Laurentia (e.g. Goodge \& Vervoort, 2006). Deformation and exhumation of basement terranes throughout southwest Laurentia between 1480 and $1400 \mathrm{Ma}$ (e.g. Nyman et al., 1994; Karlstrom \& Humphreys 1998, Shaw et al., 2005; Daniel \& Pyle 2006; Doe et al., 2012, 2013; Daniel et al., 2013) is attributed to the Picuris Orogeny, which may be a record of intracontinental deformation in response to collision along the southern margin of Laurentia (Daniel et al., 2013; Jones et al., 2015; Karlstrom et al., 2016).

The Late Mesoproterozoic Grenville Orogeny marks the culminating episode of Proterozoic accretion and termination of convergence along the long-lived (ca. $800 \mathrm{Ma}$ ) convergent margin of southwest Laurentia (Karlstrom et al., 2001). Like its continuation in northeastern Laurentia, the Grenville Orogeny in southern Laurentia records convergence, arc accretion, and continent-continent collision between ca. 1350 and 1000 Ma (Mosher, 1998; Bickford et al., 2000; Mosher et al., 2008). The Llano uplift in central Texas is interpreted as an exposed portion of the core of the Grenville orogen in southern Laurentia and contains high-grade metamorphic and magmatic rocks that were imbricated in a north-verging thrust stack during continent-continent collision (Mosher, 1998; Reese \& Mosher, 2004; Carlson et al., 2007; Mosher et al., 2008; Levine \& Mosher, 2010). The Llano uplift is divided from north to south into the Valley Springs, Packsaddle, and Coal Creek Domains (Mosher et al., 2008). Metasedimentary and metaigneous rocks of the Valley Springs and Packsaddle Domains are interpreted to represent a 12881232 Ma continent arc complex built on ca. 1360 Ma basement (Mosher et al., 1998; Reese et al., 2000). The 1330-1270 Ma Coal Creek Domain consists of a tonalite-diorite complex, serpentinized harzburgite, and island arc basalts of an accreted oceanic arc (Roback, 1996). Collision in the Llano uplift involved eclogite facies metamorphism at 1150-1120 Ma that was followed by low- to mediumpressure regional metamorphism and the intrusion of syn-and post-collisional granitoids between 1120 and 1070 Ma (Walker, 1992; Rougive et al., 1996; Mosher, 1998; Carlson et al., 2007). 
A portion of the foreland of the Grenville orogen in southern Laurentia is exposed at Van Horn, western Texas (Fig. 1) where amphibolite facies rocks of the 1380-1330 Ma Carrizo Mountain Group were interleaved with Mesoproterozoic cover sequences (Soegaard \& Callahan, 1994; Grimes \& Mosher, 2003; Davis \& Mosher, 2015). Ductile deformation and metamorphism at Van Horn occurred between 1060 and $1035 \mathrm{Ma}$ (Bickford et al., 2000; Grimes \& Mosher, 2003; Grimes \& Copeland, 2004; Davis \& Mosher, 2015), followed by final movement on the frontal thrust of the southern Grenville orogen at 1000-980 Ma (Grimes \& Copeland, 2004; Davis \& Mosher, 2015).

The Grenville Orogeny in southern Laurentia has been interpreted in the context of arc-continent and continent-continent collision (Mosher, 1998; Carlson et al., 2007; Mosher et al., 2008; Levine \& Mosher, 2010; Davis \& Mosher, 2015). The Valley Springs and Packsaddle Domains in the Llano uplift are interpreted to record 1288-1232 Ma continental arc magmatism above a north-dipping subduction zone, while in the ocean basin to the south, the Coal Creek Domain oceanic arc is interpreted to have collided with an approaching continent, generally interpreted to be the Kalahari craton (e.g. Dalziel et al., 2000; Li et al., 2008; Ksienzyk \& Jacobs, 2015), at 1270-1260 Ma (Mosher, 1998). Termination of continental arc magmatism in southern Laurentia likely occurred via a flip in subduction polarity from north- to south-dipping between 1232 and $1150 \mathrm{Ma}$ and was followed by continent-continent collision between 1150 and $1120 \mathrm{Ma}$ (Carlson et al., 2007; Mosher et al., 2008). Slab break-off following collision lead to rapid exhumation of the deeply buried margin of Laurentia and post-collisional magmatism in the Llano uplift at 1120-1070 Ma (Mosher et al., 2008). Widespread 1150-1050 Ma mafic and felsic magmatism throughout southwest Laurentia may be genetically related to slab-break off in the Llano uplift (Fig. 1, Hammond, 1990; Howard, 1991; Bright et al., 2014).

Deformation and metamorphism at Van Horn, western Texas post-dates tectonism in the Llano uplift by at least 60 million years, suggesting it represents a distinctly younger phase of the Grenville Orogeny in southern Laurentia (Grimes \& Copeland, 2004; Davis \& Mosher, 2015). The later episode of deformation and metamorphism in western Texas at 1060-980 Ma could indicate that continent-continent collision initiated earlier in the central Texas (Llano uplift) and progressed westward along the southern margin of Laurentia with time (Davis \& Mosher, 2015). Alternatively, the 60 million year difference in deformation and metamorphism between western and central Texas may reflect the collision of two separate blocks with the southern margin of Laurentia during the Grenville Orogeny (Mosher, 1998; Davis \& Mosher, 2015).

\subsection{Overview of Late Mesoproterozoic sedimentary sequences in southwest Laurentia}

Late Mesoproterozoic sedimentary sequences in southwest Laurentia have been interpreted to be broadly correlative on the basis of similar lithologies and interpreted depositional environments (Fig. 2, Shride 1967; Wrucke, 1989; Seeley, 1999; Timmons et al., 2005). Deposition above basement as young as $1330 \mathrm{Ma}$ and crosscutting ca. $1100 \mathrm{Ma}$ diabase dikes suggests that sedimentation was coincident with the Grenville Orogeny in southern Laurentia (Wrucke, 1989; Bickford et al., 2000; Timmons et al., 2005). A summary of the stratigraphy of the Late Mesoproterozoic basins of southwest Laurentia is presented below to provide context for new detrital mineral datasets that support new regional correlations and refined connections to the southern Grenville Orogeny (Figs. 1 and 2).

Complexly deformed pre- and syn-orogenic Late Mesoproterozoic sedimentary and volcanic rocks are exposed in the footwall of the frontal thrust of Grenville orogen at Van Horn in western Texas (Fig. 1). 
The oldest sequence is the Allamoore Formation, which comprises intertidal-supratidal stromatolitic dolostone, chert, mudstone, mafic volcanic rocks, and includes tuffs dated between 1256 and $1250 \mathrm{Ma}$ (Edwards, 1984; Roths, 1993; Bickford et al., 2000). The unconformably overlying Tumbledown Formation comprises volcaniclastic sandstone and basalt intercalated with megablocks of the Allamoore Formation and was deposited at $1243 \pm 10 \mathrm{Ma}$ in a tectonically active setting (Soegaard \& Callahan, 1994). The youngest sequence at Van Horn comprises alluvial fan conglomerates and eolian sandstones of the Hazel Formation, which nonconformably overlies the Tumbledown Formation (Bickford et al., 2000; Spencer et al., 2014; Davis \& Mosher, 2015). The Hazel Formation was derived from actively uplifting thrust sheets to the south at 1060-1035 Ma (Roths, 1993; Soeegard \& Callahan, 1994; Bickford et al., 2000; Grimes \& Copeland, 2004). Earlier ductile structures at Van Horn, including those in the Hazel Formation, were truncated by the frontal thrust of the southern Grenville orogen at 1000-980 Ma (King \& Flawn, 1953; Grimes \& Copeland, 2004; Davis \& Mosher, 2015).

A second exposure of Late Mesoproterozoic sedimentary and volcanic sequences in western Texas occurs in the Franklin Mountains as a roof pendant in the $1120 \pm 35$ Ma Red Bluff Granite (Pittenger, 1994; Seeley, 1999; Bickford et al., 2000). The basal Castner Marble is a package of intertidal-subtidal stromatolitic limestone with marine ${ }^{87} \mathrm{Sr} /{ }^{86} \mathrm{Sr}$ and $\delta^{13} \mathrm{C}$ isotopic signatures (Pittenger, 1994), rhythmite, conglomerate, and tuffaceous siltstone dated at $1272 \pm 5,1251 \pm 47$ (Bickford et al., 2000), and $1260 \pm$ $20 \mathrm{Ma}$ (Pittenger, 1994). Subaqueous basaltic rocks of the overlying Mundy Breccia were emplaced into unconsolidated sediments of the Castner Marble (Pittenger, 1994; Ballard, 1997). The Mundy Breccia is unconformably overlain by quartz arenite, subarkose, and mudstone of the Llanoria Formation, which were initially deposited in a marine shelf setting that was subsequently overlain by deltaic deposits (Seeley, 1999). North-directed paleocurrent indicators and soft sediment deformation features suggest the Llanoria Formation was deposited in a tectonically active basin sourced from the south (Seeley, 1999). Spencer et al., (2014) interpret the Llanoria Formation to be a lateral equivalent of the Hazel Formation in the Van Horn region based on similar detrital zircon populations (but see Figure 2 for an alternative interpretation). The $1111 \pm 48 \mathrm{Ma}$ Thunderbird Group is the youngest sequence in the Franklin Mountains and comprises felsic volcaniclastic rocks, rhyolite, and ignimbrite, which may represent the extrusive equivalents of the Red Bluff Granite (Thomann, 1980; Roths, 1993; Shannon et al., 1997).

The Debaca Group occurs in the subsurface of New Mexico and Texas and is known mainly from drill hole intersections and a small exposure in the Sacramento Mountains, New Mexico (Fig. 1). The Debaca Group comprises dolomite, volcaniclastic siltstone, arkose, and quartzite, which are intruded by $1090 \pm 4$ Ma gabbro (Flawn, 1956; Pray, 1961; Amarante, 2001). Like the Debaca Group, the Las Animas Formation of southern Colorado is a subsurface sequence and consists of a lower section of greywacke, mudstone, and chert and an upper sequence of arkose, dolomite, andesite, basalt, and tuff (Tweto, 1983).

The Apache Group of eastern Arizona contains carbonate, basalt, and siliciclastic rocks intruded by diabase between 1080 and 1094 Ma (Shride, 1967; Wrucke, 1989; Bright et al., 2014). The 1340 Ma Pioneer Shale forms the base of the Apache Group and consists of a locally-present basal conglomerate overlain by tuffaceous mudstone deposited in south-flowing alluvial fans and proximal braided streams (Shride, 1967; Middleton \& Trujillo 1984; Cullom, 1996; Stewart et al., 2001; Doe, 2014). The unconformably overlying Dripping Springs Formation comprises arkosic sandstone and shale deposited in prograding tidal flats and distal alluvial fans derived from the south (Shride, 1967; Engel \& Elmore, 
1990; Middleton \& Montgomery, 2001; Berladi-Campesi et al., 2014). The lack of juvenile volcaniclastic material (e.g. glass shards) in the Dripping Springs Formation, which is abundant in the Pioneer Shale, suggests the unconformity above the Pioneer Shale represents a significant hiatus (Shride, 1967). The Mescal Limestone overlies the Dripping Springs Formation and consists of lower dolomite containing conglomerate and slump features and an upper stromatolitic dolomite overlain by mudstone and siltstone and capped by basalt flows (Shride, 1967; McConell, 1975; Bertrand-Sarfati \& Awramik, 1992). Following basaltic volcanism, the Apache Group was uplifted and gently folded prior to deposition of the Troy Quartzite (Shride, 1967; Skotnicki \& Knauth, 2007). The lower Arkose Member of the Troy Quartzite was deposited in a north-northwest flowing braided stream complex and is overlain by westerly-derived quartz-rich eolian deposits (Shride, 1967; Weiss, 1986). The upper Chediski Member of the Troy Quartzite consists of conglomerate and quartz arenite deposited in southeast and southwest flowing braided streams and contains laterally extensive soft sediment deformation features that are interpreted to reflect syn-depositional seismicity (Shride, 1967; Burns, 1987; Wrucke, 1989).

The Unkar Group contains carbonate, siliciclastic, and mafic rocks exposed in a series of grabens in the eastern parts of Grand Canyon, Arizona (Sears, 1973; Timmons et al., 2005). Figure 3 is a composite stratigraphic section of the Unkar Group with representative lithologies and sedimentary features that are shown in Figures $3 \mathrm{~A}-\mathrm{F}$. We use the Unkar Group as the basis for regional correlations as the stratigraphy of the major depositional units have been studied in detail and the lithologies and sedimentary features of the group are similar to those preserved in other Late Mesoproterozoic sequences throughout southwest Laurentia. The lowest unit of the Unkar Group is the Bass Formation, which comprises a basal conglomerate (Hotauta member) overlain by intertidal to subtidal stromatolitic dolomite, siltstone, fine-grained sandstone(Dalton, 1972; Timmons et al., 2005). The Bass Formation is conformably overlain by marginal marine mudstone and arkose of the Hakatai Shale (Reed, 1976). Northwest-verging monoclines were active during deposition of the Bass and Hakatai sequences (Sears, 1973; Timmons et al., 2005). A low-angle unconformity separates the Hakatai Shale from cross-bedded quartz arenite comprising the Shinumo Sandstone (Fig. 3C). The Shinumo Sandstone was deposited in fluvial, marginal marine, and deltaic depositional environments with paleocurrent indicators recording north-directed flow (Daneker, 1975; Timmons et al., 2005). Soft sediment deformation is widespread throughout the Shinumo Sandstone and is interpreted to record syn-depositional seismic activity (Daneker, 1975; Middleton \& Blakey, 1988). Deltaic and marginal marine quartz arenite, arkose, and mudstone of the Dox Formation conformably overlie the Shinumo Sandstone and were sourced from the south and west (Stevenson \& Beus, 1982; Timmons et al., 2005). The upper Dox Formation interfingers with basaltic lava and volcaniclastic rocks of the $1104 \mathrm{Ma}$ Cardenas Basalt, which was emplaced during northeast-southwest extension (Hendricks, 1972; Larson et al., 1994; Weil et al., 2003; Timmons et al., 2005).

The lower parts of the Pahrump Group of Death Valley, California includes the two unconformity-bound lower and middle members of the Crystal Spring Formation (Roberts, 1982; Mahon et al., 2014). The lower Crystal Spring Formation is a fluvial-marine conglomerate succession derived from the north and fines upward into intertidal-deltaic arkose and mudstone derived from the south (Roberts, 1982). The middle unit of the Crystal Spring Formation comprises stromatolitic dolomite and siliciclastic units derived from the south (Roberts, 1982). Both the lower and middle members of the Crystal Spring Formation were intruded by diabase at $1069 \pm 3$ and $1087 \pm 3$ Ma (Heaman \& Grotzinger, 1992). 


\subsection{Analytical Methods}

Sample location information and stratigraphic context of detrital mineral samples collected during this study are presented in Supplementary File 1.

\subsection{Detrital Zircon U-Pb analysis}

Detrital zircon samples were processed by standard separation techniques and mounted in epoxy with the Sri Lanka primary standard and R33 and FC-1 secondary standards (Gehrels et al., 2008; Gehrels \& Pecha, 2014). Zircons were analyzed via Laser Ablation-Inductively Couple Plasma Mass Spectrometry at the Arizona LaserChron Center following the methods outlined by Gehrels et al. (2008) and Gehrels \& Pecha (2014). Approximately one hundred zircon grains from each sample were selected randomly for analysis with the placement of analysis spots aided by cathodoluminesence and Back Scattered Electron images. Analytical data are presented in Supplementary File 2. Detrital zircon age data are plotted as probability distribution plots with Isoplot version 3.1 (Ludwig, 2003) using ${ }^{207} \mathrm{~Pb} /{ }^{206} \mathrm{~Pb}$ ages and $1 \sigma$ uncertainties for analyses between 80 and 105\% concordant (Fig. 4). The Unmix algorithm of Isoplot (Sambridge \& Compston, 1994; Ludwig, 2003) was used to explore the distribution of ages for the youngest zircons (1350-1100 Ma) in the major depositional units of each basin (Table 1). Full analytical results are reported in Supplementary File 2 and probability density plots and concordia plots for all samples analysed during this study are included in Supplementary Files 3 and 4.

\subsection{Detrital muscovite and biotite ${ }^{40} \mathrm{Ar} /{ }^{39} \mathrm{Ar}$ analysis}

Detrital muscovite and biotite samples were crushed, washed, and sieved, followed by hand picking of 50-100 crystals from the 60-90 sieve fraction. Step heating and total fusion experiments were conducted at the New Mexico Geochronology Research Laboratory, New Mexico Institute of Mining and Technology, using a Synrad $50 \mathrm{~W} \mathrm{CO}_{2}$ laser beam coupled to a MAP 215-50 mass spectrometer. Full details of the instrumental set up, analytical protocols, and details of plateau age calculations and correction factors applied to the total fusion ages follow Fletcher (2005) and are outlined in Supplementary File 5 . The step heated and total fusion ages are combined in probability distribution plots using $1 \sigma$ uncertainties (Fig. 4) and the full analytical results are reported in Supplementary Files 6 and 7. The ${ }^{40} \mathrm{Ar} /{ }^{39} \mathrm{Ar}$ ages derived from the detrital micas reflect the time at which rocks in the source region cooled through the closure temperature of Ar diffusion for the respective micas. These cooling age are a function of grain size and cooling rate and range from $300-420^{\circ} \mathrm{C}$ for muscovite (Purdy \& Jager, 1976) and $280-345^{\circ} \mathrm{C}$ for biotite (Harrison et al., 1985). We use $350^{\circ} \mathrm{C}$ and $300^{\circ} \mathrm{C}$ as the general cooling temperatures for muscovite and biotite respectively.

\subsection{Results}

Detrital mineral results for each of the Late Mesoproterozoic basins of southwest Laurentia are discussed in order of increasing distance from the Grenville orogenic front in southern Laurentia (Figs. 1 and 2) and are summarized in probability density plots that integrate new and previously published detrital zircon, muscovite, and biotite ages. Figure 5 is an enlargement of the $1350-1000 \mathrm{Ma}$ age window for the same data presented in Figure 4, which highlights the distribution of 'Grenville-aged' (1300-1000 Ma) detritus in the Late Mesoproterozoic basins of southwest Laurentia. Colour bands in 
Figures 4 and 5 correspond to the duration of tectonic events in the Llano uplift during the Grenville Orogeny in southern Laurentia (after Mosher et al., 2008) and age ranges for basement provinces throughout southwest Laurentia (Fig. 1).

\subsection{Detrital zircon results}

\subsubsection{Western Texas Sequences}

The detrital zircon dataset from the Late Mesoproterozoic sequences in western Texas includes 124 concordant analyses from 2 new samples of the Llanoria Formation in addition to the 142 analyses of the Llanoria Formation and 94 analyses of the Hazel Formation published by Spencer et al. (2014). Approximately $35 \%$ of the detrital zircons analyzed from the Llanoria Formation have Paleoproterozoic crystallization ages, which form an age peak at $1872 \mathrm{Ma}$. Mesoproterozoic zircon ages from the Llanoria Formation include age peaks at $1441 \mathrm{Ma}, 1293$, and $1229 \mathrm{Ma}$ (Table 1 and Fig. 4). In contrast to Spencer et al. (2014), we interpret the small population at ca. $1080 \mathrm{Ma}$ from the Llanoria Formation to reflect zircons affected by $\mathrm{Pb}$-loss as this age is younger than the overlying $1111 \mathrm{Ma}$ Thunderbird Group and crosscutting 1120 Ma Red Bluff Granite (Bickford et al., 2000). Paleoproterozoic zircon ages comprise $15 \%$ of the total analyses from the Hazel Formation with the largest age peak occurring at $1801 \mathrm{Ma}$. Approximately $20 \%$ of zircons from the Hazel Formation are assigned to an age peak at $1441 \mathrm{Ma}$, which is flanked by a minor younger peak at $1360 \mathrm{Ma}$ comprising 3 analyses and an older peak at $1549 \mathrm{Ma}$ comprising 4 analyses. 'Grenville-aged' zircons comprise $65 \%$ of the Hazel Formation dataset and form age peaks at 1263,1205 , and $1130 \mathrm{Ma}$ (Table 1). Note that the age peaks quoted above for the Hazel Formation differ from those reported by Spencer et al. (2014) due to the more conservative concordance limits used in this study.

\subsubsection{Debaca Group}

The new Debaca Group dataset includes 67 concordant analyses from the exposure in the Sacramento Mountains, New Mexico. The new dataset greatly bolsters the detrital record of this poorly known sequence, which was previously restricted to 5 concordant zircons analyzed from the Mescalero 1 Well (Fig. 1, Barnes 2001; Amarante, 2001). The oldest age peaks in the Debaca Group dataset occur at 1686 and $1609 \mathrm{Ma}$. Early Mesoproterozoic (1600-1500 Ma) crystallization ages comprise 25\% of the total population and form an age peak at $1542 \mathrm{Ma}$. The youngest detrital zircon age population in the Debaca Group occurs at $1304 \mathrm{Ma}$ (10 grains). 
Table 1: Youngest detrital zircon analysis

\begin{tabular}{|c|c|c|c|c|c|}
\hline Unit/Basin & $\begin{array}{l}\text { Interpreted age } \\
\text { (Ma) }\end{array}$ & $\begin{array}{l}\text { Age of Young } \\
\text { Populations } \\
\text { (Ma) }\end{array}$ & $\pm 1 \sigma$ & $\begin{array}{c}\text { Number of } \\
\text { grains in young } \\
\text { population }\end{array}$ & $\begin{array}{c}\text { Percentage of young } \\
\text { population of the } \\
\text { total } 1350-1000 \mathrm{Ma} \\
\text { analyses }\end{array}$ \\
\hline \multicolumn{6}{|l|}{ Western Texas } \\
\hline \multirow[t]{2}{*}{ Llanoria Formation. } & $1140-1100$ & 1229 & 3 & 57 & 80 \\
\hline & & 1293 & 8 & 14 & 20 \\
\hline \multirow[t]{2}{*}{ Hazel Formation } & $1130-1035$ & 1130 & 5 & 28 & 46 \\
\hline & & $\begin{array}{l}1205 \\
1263\end{array}$ & $\begin{array}{c}7 \\
11 \\
\end{array}$ & $\begin{array}{c}26 \\
6 \\
\end{array}$ & $\begin{array}{l}43 \\
10\end{array}$ \\
\hline Debaca Group* & $1300-1090$ & 1304 & - & 10 & 100 \\
\hline \multicolumn{6}{|l|}{ Apache Group } \\
\hline Pioneer Shale* & 1340 & 1338 & - & 40 & 100 \\
\hline Dripping Springs & $1255-1230$ & 1256 & 3 & 15 & 31 \\
\hline Formation & & 1327 & 2 & 32 & 69 \\
\hline \multirow[t]{2}{*}{ Troy Quartzite } & $1140-1100$ & 1259 & 3 & 94 & 96 \\
\hline & & 1325 & 19 & 4 & 4 \\
\hline \multicolumn{6}{|l|}{ Unkar Group } \\
\hline \multirow[t]{2}{*}{ Bass Formation } & $1255-1230$ & 1234 & 1.7 & 129 & 75 \\
\hline & & 1302 & 4.8 & 43 & 25 \\
\hline \multirow[t]{2}{*}{ Hakatai Shale } & $1255-1230$ & 1243 & 2 & 149 & 75 \\
\hline & & 1317 & 3 & 50 & 25 \\
\hline \multirow[t]{4}{*}{ Shinumo Sandstone } & $1140-1100$ & 1111 & 9 & 4 & 3 \\
\hline & & 1184 & 5 & 35 & 27 \\
\hline & & 1230 & 5 & 36 & 28 \\
\hline & & 1282 & 2 & 55 & 43 \\
\hline \multirow[t]{3}{*}{ Dox Formation } & $1140-1100$ & 1201 & 4 & 33 & 32 \\
\hline & & 1256 & 5 & 37 & 36 \\
\hline & & 1309 & 3 & 32 & 31 \\
\hline \multicolumn{6}{|l|}{ lower Pahrump Group } \\
\hline lower Crystal Springs* & 1320 & 1323 & - & 3 & 100 \\
\hline middle Crystal Springs* & $1255-1230$ & 1210 & - & 4 & 100 \\
\hline
\end{tabular}

*single young population, quoted age is the youngest peak on probability distribution plot. 


\subsubsection{Apache Group}

The probability density distribution of the 163 concordant analyses from the Pioneer Shale contains a small grouping of age peaks between 2400 and $2600 \mathrm{Ma}$, a prominent age peak at $1650 \mathrm{Ma}$, and a smaller age peak at $1430 \mathrm{Ma}$. The youngest zircon population from the Pioneer Shale occurs at $1338 \mathrm{Ma}$ and includes approximately $24 \%$ of the detrital zircons analyzed from this unit. The Pioneer Shale dataset contains no 'Grenville-aged' (1300-1000 Ma) zircons. The Dripping Springs Formation dataset contains 383 new analyses to compliment the 20 analyses previously published by Stewart et al. (2001). Detrital zircons from the Dripping Springs Formation form populations at 2600-2400 Ma, 1800-1600 $\mathrm{Ma}, 1440 \mathrm{Ma}$, all of which closely match the age peaks found in the underlying Pioneer Shale and also contains spread of ages between 1400 and 1300 Ma. However, unlike the Pioneer Shale, $12 \%$ of the detrital zircons from the Dripping Springs Formation have $<1350$ Ma crystallization ages, which form age peaks at 1327 and $1256 \mathrm{Ma}$ (Table 1 and Fig. 5). The 118 new analyses from the Troy Quartzite and 13 analyses published by Stewart et al. (2001) have a minor spread of Paleoproterozoic ages (1800-1600 $\mathrm{Ma}$ ) and a $1450 \mathrm{Ma}$ age peak. The Troy Quartzite dataset is dominated by a large age peak centered on $1259 \mathrm{Ma}$, which contains nearly half of the concordant analyses from the 3 samples.

\subsubsection{Unkar Group}

All units within the Unkar Group contain a complex distribution of Paleoproterozoic zircons typically between 1800-1600 Ma, large age peaks at ca. $1450 \mathrm{Ma}$, and a young populations between 1300$1200 \mathrm{Ma}$ (Figs. 4 and 5). Approximately $70 \%$ of the 640 concordant detrital zircons from the Bass Formation analyzed during this study have crystallization ages $>1400 \mathrm{Ma}$, which form two age peaks at $1450 \mathrm{Ma}$ and $1732 \mathrm{Ma}$, and a minor distribution of ages between 2675 and $2450 \mathrm{Ma}$. The youngest detrital zircon population from the Bass Formation forms an age peak at $1234 \mathrm{Ma}$ with a shoulder of older ages extending between 1285 and 1354 Ma with an age peak at $1302 \mathrm{Ma}$ (Table 1 and Fig. 5). The detrital zircon dataset from the Hakatai Shale includes 256 new analyses in addition to the 77 analyses published by Timmons et al., (2005) and 53 analyses published by Bloch et al. (2006). Detrital zircons from the Hakatai Shale form a relatively simple probability distribution that includes a minor group of Paleoproterozoic grains between 1600 and $1800 \mathrm{Ma}$ and a major age peak at $1452 \mathrm{Ma}$, which forms 52\% of the total analyses. The youngest zircons in the Hakatai Shale form an age peak at $1243 \mathrm{Ma}$ and a second smaller peak at $1317 \mathrm{Ma}$ (Table 1 and Fig. 5).

The Shinumo Sandstone dataset includes 334 new analyses collected during this study to compliment the 88 analyses published by Timmons et al., (2005) and 168 analyses published by Bloch et al., (2006). Unlike the lower units of the Unkar Group, the Shinumo Sandstone contains abundant Late ArcheanEarly Paleoproterozoic zircons forming a complex age distribution between 2400 and $2800 \mathrm{Ma}$ (Fig. 4). The majority of Paleoproterozoic detrital zircons from the Shinumo Sandstone have crystallization ages between 1600 and $2000 \mathrm{Ma}$, which represent 42\% of the total population from this unit.

Mesoproterozoic zircons from the Shinumo Sandstone form an age peak at $1440 \mathrm{Ma}$ and a complex distribution of age peaks between 1183 and $1305 \mathrm{Ma}$, the largest of which occurs at $1282 \mathrm{Ma}$ (Table 1). Ages between 1000 and $1180 \mathrm{Ma}$ are interpreted to be derived from zircons affected by Pb-loss as they generally have low precision and form only a single minor age peak at $1111 \mathrm{Ma}$, which consists of only 4 zircons (Table 1). Over half (55\%) of the 1000-1180 Ma analyses from the Shinumo Sandstone come from a single sample (T01-75-7) that also yields detrital zircons with ages younger than the $1104 \mathrm{Ma}$ depositional age of the overlying Cardenas Basalt, which supports the interpretation that zircons in sample T01-75-7 have experienced Pb-loss. Our preferred youngest age peak in the Shinumo Sandstone 
dataset occurs at $1184 \mathrm{Ma}$ and consists of 35 individual analyses representing $27 \%$ of the total ages between 1100 and $1350 \mathrm{Ma}$ from this unit (Table 1 and Fig. 5). We present 152 new analyses from the Dox Formation in addition to the 92 analyses published by Timmons et al., (2005) and the 72 analyses of Bloch et al., (2006). The Dox Formation dataset contains a small population of Late Archean to Early Paleoproterozoic zircons between 2400 and $2600 \mathrm{Ma}$, a broad distribution of ages at 1600-2000 Ma, and a prominent 1440 Ma population. Detrital zircons with crystallization ages <1350 Ma comprise 33\% of the total analyses from the Dox Formation and form a cluster of age peaks at $1201 \mathrm{Ma}, 1256 \mathrm{Ma}$, and 1309 Ma (Table 1).

\subsubsection{Lower Pahrump Group}

The two detrital zircon samples from the lower member of the Crystal Spring Formation reported by Mahon et al., (2014) are dominated by Paleoproterozoic zircons with $96 \%$ of the analyses having ages between 1600 and $1900 \mathrm{Ma}$ and a minor scatter of ages between 2000 and $2700 \mathrm{Ma}$. The youngest detrital zircons from the lower member of the Crystal Spring Formation form a small age peak at 1323 Ma (3 grains). Detrital zircon data from the middle member of the Crystal Spring Formation collected during this study (62 concordant analyses) form a complicated age distribution, which includes age peaks between 2450 and $2880 \mathrm{Ma}$, and a grouping of Paleoproterozoic peaks between 1700 and 1900 Ma. Mesoproterozoic detrital zircons form an age peak at $1596 \mathrm{Ma}$ and include 25 grains that form a broad spread of ages between 1100 and $1350 \mathrm{Ma}$, with a possible age peak at 1210 Ma comprising 4 analyses.

\subsection{Detrital Mica Results}

Detrital muscovite was analyzed from almost all of the major stratigraphic units from each of the Late Mesoproterozoic basins of southwest Laurentia with the exception of the sequences in western Texas. Approximately 1001 new analyses of detrital muscovite grains from 24 samples are summarized (in red)

along with the detrital zircon probability distribution plots in Figures 4 and 5 . The muscovite data include analyses from both step heating and total fusion experiments. The spread in ages derived from the two different methods generally overlap, so that the sharp peaks from the higher precision step heated ages are superimposed over broader peaks from the lower precision total fusion method. Therefore, although the majority of ages quoted from the probability density plots in Figures 4 and 5 reflect discrete populations of step heated data, these age peaks are also representative of the total fusion results for a given sample (Supplementary File 5).

\subsubsection{Debaca Group}

The Debaca Group detrital muscovite ages are spread between 1000 and $1530 \mathrm{Ma}$ and are dominated by a cluster of age peaks between 1000 and $1460 \mathrm{Ma}$ (Fig. 4). Paleoproterozoic cooling ages are rare (7 of 108 analyses) and form minor peaks between 1600 and $1700 \mathrm{Ma}$. The youngest cooling ages form a broad distribution between 1000 and $1400 \mathrm{Ma}$, which includes peaks at $1180 \mathrm{Ma}, 1300 \mathrm{Ma}, 1336 \mathrm{Ma}$, and $1370 \mathrm{Ma}$. Approximately $20 \%$ of the analyses from the Debaca Group produce a spread of lowprecision ages from 100 to $1000 \mathrm{Ma}$, which are interpreted to represent crystals affected by Ar-loss. 


\subsubsection{Apache Group}

Detrital muscovite cooling age distributions throughout the Apache Group stratigraphy are characterized by the persistence of a large 1450 Ma cooling age peak and a scarcity of <1400 Ma cooling ages. Cooling ages from the Pioneer Shale form a cluster of age peaks between 1370 and $1450 \mathrm{Ma}$ and a minor, broad distribution between 1500 and 1800 Ma. Detrital muscovite from the Dripping Springs Formation has a complex cooling age spectrum characterized by a prominent double peak at 1410-1420 $\mathrm{Ma}$, which is flanked by clusters of smaller peaks between 1510 and $1590 \mathrm{Ma}$ and a second cluster of peaks between 1440 and 1470 Ma. Younger cooling ages from the Dripping Springs Formation include peaks between 1230 and $1320 \mathrm{Ma}$ and two minor peaks at 1110 and $1180 \mathrm{Ma}$. An influx in detrital muscovite with Paleoproterozoic cooling ages is recorded in the upper most Apache Group by the Troy Quartzite and form a spread of ages between 1600 and 1710 Ma with a prominent age peak at 1660 Ma. As with the underlying stratigraphy of the Apache Group, <1400 Ma cooling ages are rare in the Troy Quartzite with a minor peak at 1230 Ma reflecting a single total fusion analysis.

\subsubsection{Unkar Group}

Detrital muscovite cooling ages from the basal conglomerate (Hotauta Member) of the Bass Formation (lower Unkar Group) define a relatively simple probability density distribution characterized by a prominent peak at $1710 \mathrm{Ma}$ and a small peak derived from a single total fusion analysis at $1450 \mathrm{Ma}$ (Fig. 4). In contrast to the Bass Formation, the Dox Formation (upper Unkar Group) contains abundant Late Mesoproterozoic detrital muscovite with $97 \%$ of analyses producing cooling ages $<1300 \mathrm{Ma}$. The probability distribution plot for the Dox Formation contains 450 analyses obtained during this study in addition to the 82 analyses reported by Timmons et al. (2005) and is dominated by two large age peaks at $1152 \mathrm{Ma}$ and $1160 \mathrm{Ma}$ and spread of older ages up to $1250 \mathrm{Ma}$ including peaks at $1172 \mathrm{Ma}, 1188 \mathrm{Ma}$, and $1205 \mathrm{Ma}$. A minor peak occurs at $1123 \mathrm{Ma}$ and comprises 13 analyses that may represent the youngest detrital muscovite population for the Dox Formation. However, only 1 of the 10 analyses obtained during this study assigned to the 1123 Ma peak is a precise step heated age. We prefer a more conservative estimate of the youngest detrital muscovite population in this sample derived from the next youngest peak at $1152 \mathrm{Ma}$, which contains 66 individual analyses, including 15 step heated ages. There is no appreciable difference in the muscovite ages derived from each of the members of the Dox Formation with both total fusion and step heated data from the individual members containing the 1150-1250 Ma spread of ages observed in the combined probability density plot (Table 2 and Figs. 4 and 5). The major 1140 Ma detrital muscovite age peak reported by Timmons et al. (2005) from the basal member of the Dox Formation was not reproduced in any of the new samples analyzed during this study but forms a prominent shoulder on the 1152 Ma peak in the combined probability density plot (Fig. 5). Detrital biotite from the Solomon Temple Member of the Dox Formation has a spread of ages between 1030 and $1190 \mathrm{Ma}$, forming a broad age peak centered on $1146 \mathrm{Ma}$. We interpret this $1146 \mathrm{Ma}$ peak to be the youngest reliable detrital mica cooling age peak from the Dox Formation, which agrees with the 1140 Ma maximum depositional age for the Dox Formation based on the detrital muscovite data reported by Timmons et al. (2005). 
Table 2: Number of detrital muscovite analyses by method and major cooling age peaks for each member of the Dox Formation, Unkar Group (data from this study only).

\begin{tabular}{lccc}
\hline Member & $\begin{array}{c}\text { Total Fusion } \\
\text { Analyses }\end{array}$ & $\begin{array}{c}\text { Step Heated } \\
\text { Analyses }\end{array}$ & Age Peaks (Ma) \\
\hline Escalante Creek & 103 & 55 & $1160,1200,1220$ \\
Solomon Temple & 55 & 10 & $1150,1160,1200,1220$ \\
Comanche Point & 75 & 0 & 1160 \\
Ochoa Point & 92 & 11 & 1160,1230 \\
\hline
\end{tabular}

\subsubsection{Lower Pahrump Group}

Detrital muscovite from the lower member of the Crystal Spring Formation define a complex cooling age spectrum with a spread of ages from 1080 to $1670 \mathrm{Ma}$. Paleoproterozoic cooling ages comprise $57 \%$ of the analyses and form a large age peak at $1620 \mathrm{Ma}$. Mesoproterozoic cooling ages include peaks at 1440 $\mathrm{Ma}, 1560 \mathrm{Ma}$, and $1580 \mathrm{Ma}$ and series of small broad peaks extending from 1080 to $1300 \mathrm{Ma}$.

\subsection{Discussion}

\subsection{Provenance of Late Mesoproterozoic Sequences}

Integrating the detrital zircon and mica datasets refines the correlation of sedimentary successions and provenance of the Late Mesoproterozoic basins of southwest Laurentia by revealing the crystallization age of rocks in the source region as indicated by detrital zircon ages and the time at which source regions most recently passed through the closure temperature for muscovite $\left(300-420^{\circ} \mathrm{C}\right.$, Purdy \& Jager, 1976) and biotite $\left(280-345^{\circ} \mathrm{C}\right.$, Harrison et al., 1985).

\subsubsection{Detrital zircon provenance}

The detrital zircon record of Late Mesoproterozoic basins of southwest Laurentia show broad similarities to one another; most of the major depositional units are characterized by 1600-1800 Ma distributions, prominent age peaks at $1440-1450 \mathrm{Ma}$, and Late Mesoproterozoic populations that typically form age peaks between 1230 and $1250 \mathrm{Ma}$ (Fig. 5). We suggest the overall similarity of the detrital zircon populations of Late Mesoproterozoic strata in southwest Laurentia reflects derivation of these sequences from broadly similar sources, which are discussed on a regional basis below.

Of the 3457 concordant zircons analyses included in this study, 14\% have Archean or pre-1800 Ma Paleoproterozoic ages and 32\% have ages between 1600 and $1800 \mathrm{Ma}$. We interpret the source of the 1600-1800 Ma detrital zircons to be metaigneous and metasedimentary sequences of the Yavapai and Mazatzal terranes (Fig. 1). Archean and pre-1800 Ma Early Paleoproterozoic detrital zircons are less common in the Late Mesoproterozoic southwest Laurentian basins but form notable age distributions in the Llanoria Formation, upper Unkar Group, and middle Crystal Spring Formation (Fig. 4). The >1800 Ma 
detrital zircons in the middle member of the Crystal Spring Formation were likely derived from local Paleoproterozoic metasedimentary sequences in the Mojave province, which contain 1800-1900 Ma and Archean zircons (e.g. Wooden et al., 2012). We suggest the $>1800$ Ma zircons in the upper Unkar Group were sourced locally from recycling of the Paleoproterozoic Vishnu Schist, which contains an approximately bimodal detrital zircon age distribution with broad age peaks at 2400-2800 Ma and 1740-2000 Ma and was likely derived from the Mojave province (Schufeldt et al., 2010; Holland et al., 2015). A similar source in the Mojave province, or sedimentary sequences derived from the Mojave province, may account for the $1872 \mathrm{Ma}$ age population in the Llanoria Formation.

Only the sample of the Debaca Group contains appreciable (25\% of the total population) $1500-1600$ Ma detrital zircons (Fig. 4). The 1500-1600 Ma interval is defined as the North American Magmatic Gap as crust of this age is rare in exposed Laurentian basement terranes (Bowring \& Karlstrom, 1990; Ross \& Villeneuve, 2003; Karlstrom et al., 2004). However, 1500-1600 Ma detrital zircons are found in the 1500-1450 Ma Yankee Joe Formation of central Arizona (Doe et al. 2012; 2013) and Trampas Group of New Mexico (Daniel et al., 2013) and are interpreted to have been derived from basement terranes outside of Laurentia (perhaps Australia). Although more data are required, we interpret at least part of the 1300-1090 Ma Debaca Group to have been derived from recycling of the Yankee Jo Formation and Trampas Group successions.

Approximately $19 \%$ of the total zircon population has ages between $1400-1500 \mathrm{Ma}$ and there are major age peaks between 1440 and $1450 \mathrm{Ma}$ in most samples. The 1400-1500 Ma zircons were likely sourced from voluminous A-type granites in the southern Granite-Rhyolite Province and from granites that intrude Paleoproterozoic basement terranes throughout southwest Laurentia. Only $4 \%$ of the detrital zircons in the total dataset have ages between 1400 and $1350 \mathrm{Ma}$, which may have been derived from felsic igneous rocks in southern Granite-Rhyolite Province or the 1380-1330 Ma Carrizo Mountain Group (Figs. 1 and 2).

The remaining $28 \%$ of detrital zircons in the dataset have $<1350$ Ma ages that generally form age peaks at 1230-1300 Ma (Table 1). A plausible source region for these younger zircons is the southern GraniteRhyolite Province, which although dominated by $>1350$ Ma plutons, records magmatism as young as $1320 \mathrm{Ma}$ (Bickford et al., 2015). A second source region for <1350 Ma zircons is the 1288-1232 Ma continental arc complex preserved in the Valley Springs and Packsaddle Domains of the Llano uplift (Mosher et al., 2008). The continental arc rocks in the Llano uplift may also account for the 1230-1250 Ma detrital zircon populations, which are common in the Late Mesoproterozoic basins of southwest Laurentia. Detrital zircons with crystallization ages between the end of continental arc activity at 1232 $\mathrm{Ma}$ and the onset of syn-collisional magmatism in the Llano uplift at $1150 \mathrm{Ma}$ are rare in the Late Mesoproterozoic basins of southwest Laurentia (Table 1 and Fig. 5). Units with notable 1150-1232 Ma age peaks include the Hazel Formation (1205 Ma), Dox Formation (1201 Ma), and Shinumo Sandstone (1184 Ma). The 1180-1200 Ma detrital zircons from these three units could have been derived from rocks formed during continued (i.e. post-1232 Ma) magmatism along the southern margin of Laurentia, but which are no longer exposed. An alternative source is 1200-1180 Ma Anorthosite-MagneriteCharnockite-Granite suites in the San Gabriel and Eagle Mountains of California (Fig. 1, Barth et al., 2001; Wooden et al., 2012). 


\subsubsection{Detrital muscovite provenance}

As with the detrital zircon dataset, detrital muscovite data from most of the Late Mesoproterozoic sequences throughout southwest Laurentia show broad similarities between basins and are interpreted to have been derived from similar source regions. Detrital muscovite from Late Mesoproterozoic strata throughout southwest Laurentia are dominated by $>1400$ Ma cooling ages (Fig. 4). Approximately $54 \%$ of the $>1400$ Ma cooling ages occur between 1400-1500 Ma and form major age peaks between 1420 and $1450 \mathrm{Ma}$ in most samples. The ca.1450 Ma detrital muscovite is likely derived from the basement terranes of southwest Laurentia, which preserve widespread 1400-1500 Ma muscovite cooling ages reflecting magmatism and the exhumation associated with the Picuris Orogeny (Shaw et al., 2005; Daniel et al., 2013; Jones et al., 2015). The common 1600-1700 detrital muscovite ages likely reflect unroofing of basement terranes in southwest Laurentia that were less affected by $1400-1500 \mathrm{Ma}$ thermal overprinting (e.g. Shaw et al., 2005).

Detrital muscovite with 1500-1600 Ma cooling age peaks occur in the Debaca Group, Pioneer Shale, and lower member of the Crystal Spring Formation (Fig. 4). Similar to our interpretation for the 15001600 Ma detrital zircons in the Debaca Group, these detrital muscovites may have been recycled from the Early Mesoproterozoic Yankee Jo Formation and Trampas Group, which contain 'exotic' 1500-1600 Ma detritus, possibly derived from outside of Laurentia.

In contrast to the other Late Mesoproterozoic sequences, the detrital muscovite dataset from the Dox Formation (upper Unkar Group) is dominated by $<1400 \mathrm{Ma}$ cooling ages, which are mostly between 1160-1200 (Fig. 5). Mica with cooling ages <1400 Ma are uncommon in the basement terranes of southwest Laurentia (Shaw et al., 2005), which suggests that the Grenville orogen of southern Laurentia is the probable source for detrital muscovite and biotite in the Dox Formation. Detrital muscovite and biotite in the Dox Formation are unlikely to have been derived from the core of the Grenville orogen as the Dox Formation contains few detrital zircons with ages coincident with 1120-1150 Ma high-grade metamorphic and plutonic rocks exposed in the Llano uplift. Instead, detrital mica in the Dox Formation are interpreted to have been sourced from the structurally high parts of the orogen, which may have consisted of imbricated thrust sheets of the southern margin of Laurentia (i.e. 1232-1288 Ma continental arc rocks). Exhumation of 1232-1288 Ma crust from depths of approximately $10-15 \mathrm{~km}$ (i.e. depths corresponding to the $280-450^{\circ} \mathrm{C}$ closure temperatures of biotite and muscovite) by thrust stacking during the early stages of continent-continent collision (i.e. before the onset of 1150-1120 Ma high-grade metamorphism and magmatism) therefore provides a suitable source for Late Mesoproterozoic detrital zircon, muscovite, and biotite in the Dox Formation (Fig. 5).

Interestingly, the Troy Quartzite, which is broadly time-equivalent to the Dox Formation (Fig. 2), contains abundant 1200-1300 Ma detrital zircons but few detrital muscovites with <1400 Ma cooling ages (Fig. 4). The detrital muscovite record of the Troy Quartzite is instead dominated by ca. $1450 \mathrm{Ma}$ and 1600-1700 Ma cooling ages (Fig. 4). The Troy Quartzite is interpreted to have been sourced in part from Paleoproterozoic muscovite-rich, zircon-poor pelitic metasedimentary rocks, which can account for the abundance of 1600-1700 Ma detrital muscovite and scarcity of Paleoproterozoic detrital zircons in the dataset (Fig. 4). The abundance of 1200-1300 Ma detrital zircon in the Troy Quartzite suggests a source within the Grenville orogen to the south. However, unlike the Dox Formation, the Troy Quartzite did not receive abundant 1160-1200 Ma detrital muscovite from the Grenville orogen. We suggest that in addition to local Paleoproterozoic and Mesoproterozoic basement, the Troy Quartzite was sourced in 
part from a zircon-rich, muscovite-poor source within the Grenville orogen, possibly a metaluminous granitic or volcanic suite.

In summary, the detrital mineral record of Late Mesoproterozoic sedimentary sequences in southwest Laurentia is consistent with a combination of source regions including local Paleoproterozoic and Mesoproterozoic basement terranes and more distal sources in the Grenville orogen to the south. The provenance of the Late Mesoproterozoic basins highlights a complex interplay between local and distal transport systems that in some cases resulted in detrital zircon being derived from a distinctly different source region than detrital muscovite in the same sample.

\subsection{A new tectonic model for Late Mesoproterozoic basin formation in southwest Laurentia}

Integration of the new detrital mineral dataset, basin sedimentology and stratigraphy, and recent models for the tectonic evolution of the Grenville Orogeny in southern Laurentia (e.g. Carlson et al., 2007, Mosher et al. 2008, Levine \& Mosher, 2010, Davis \& Mosher 2015), allows us to refine the depositional age and correlation of Late Mesoproterozoic basins in southwest Laurentia. The refinements to the depositional age and correlation of Late Mesoproterozoic basins in southwest Laurentia help to place this widespread episode of sedimentation into a regional tectonic framework.

The new tectonic model for Late Mesoproterozoic basin formation in southwest Laurentia is depicted in map and cross sectional views in Figure 6. Time periods in Figure 6 are keyed to the color bands in Figures 4 and 5 and include the four key tectonic intervals during the southern Grenville Orogeny (adapted from Mosher et al., 2008 and Davis \& Mosher, 2015) and the sedimentary response in the continental interior.

\subsubsection{0-1320 Ma basin evolution}

The earliest phase of sedimentation considered in this study is preserved in the Pioneer Shale (Apache Group) and the lower member of the Crystal Spring Formation of the Pahrump Group (Figs. 1 and 2). Both formations are northerly-derived fluvial successions and were previously correlated based on lithological similarities and stratigraphic position (Shride, 1967; Wrucke, 1989; Seeley, 1999). Detrital zircon data provide further support for correlation as both sequences share large age peaks between 1600-1800 Ma and youngest detrital zircon populations at 1320-1340 Ma (Fig. 4). The 1320-1340 Ma zircon population is interpreted to reflect the depositional age of the Pioneer-lower Crystal Spring sequences as the Pioneer Shale contains abundant tuffaceous mudstone, which we interpret to have been derived from a syn-sedimentary volcanic source that contributed to the youngest detrital zircon age peak at $\mathrm{ca}$. $1340 \mathrm{Ma}$ (Fig. 4). The 1340-1320 Ma age range coincides with back arc basin sedimentation and magmatism in the 1380-1330 Ma Carrizo Mountain Group in western Texas (Bickford et al., 2000). The Pioneer Shale-lower Crystal Spring Formation may therefore be distal equivalents of the Carrizo Mountain Group and together represent a once extensive back arc basin system associated with convergence along the southern margin of Laurentia at 1380-1320 Ma.

\subsubsection{5-1230 Ma retroarc basin sedimentation}

The Pioneer Shale is unconformably overlain by the Dripping Springs Formation, which has maximum depositional age of $1250 \mathrm{Ma}$ based on our new detrital zircon data. This indicates that a hiatus of at least 70 million years followed deposition of the 1340-1320 Ma distal back arc basin sequences of the 
Pioneer Shale and lower member of Crystal Spring Formation. Uplift and erosion during this hiatus may have removed much of the 1340-1320 Ma back arc basin system and was followed by a change in the sedimentary regime to widespread shallow water carbonate sedimentation. Distinctive $100-500 \mathrm{~m}$ thick sequences of intertidal to subtidal to intertidal, stromatolitic dolomite occur in all Late Mesoproterozoic basins in southwest Laurentia except the poorly known Debaca Group and Las Animas Formation (Fig. 2). Despite lacking the characteristic stromatolitic intervals, we interpreted the thick dolomite units in the lower Debaca Group to be correlative with the Late Mesoproterozoic carbonatebearing sequences elsewhere in southwest Laurentia. These widespread carbonate sequences are likely correlative with the Bass Formation in the Unkar Group, which was deposited between 1255 and 1230 Ma based on the new detrital zircon ages from sandstones in the upper Bass Formation, which overlie a $1254.8 \pm 1.6 \mathrm{Ma}$ tuff (Timmons et al., 2005). The 1250-1240 Ma tuffs in the carbonate sequences of western Texas (Allamoore Formation and Castner Marble) provide further support for correlating the Late Mesoproterozoic carbonate-bearing sequences of southwest Laurentia. Sedimentary structures indicating episodic sub-aerial exposure and marine ${ }^{87} \mathrm{Sr} /{ }^{86} \mathrm{Sr}$ isotopic signatures from the Castner Marble in western Texas (Pittenger, 1994) indicate that deposition of the 1255-1230 Ma carbonate sequences occurred in restricted marine basins. Intraformational conglomerates, syn-sedimentary monoclines, and mafic magmatism indicate a tectonically active setting for the carbonate basins (Sears, 1973; Timmons et al., 2005). The age of $1255-1230 \mathrm{Ma}$ carbonate successions overlaps with $1288-1232 \mathrm{Ma}$ continental arc magmatism along the southern margin of Laurentia and suggests deposition in an extensive retroarc basin system as depicted in Figure 6A.

Retroarc basins form by a combination of lithospheric flexure due to development of a continental arc and lithospheric subsidence induced by coupling of the upper plate with convecting asthenosphere above the subducting slab (Fig. 6A, Mitrovica et al., 1989; Gurnis, 1992; DeCelles \& Giles 1996). The dynamic mantle effect can cause subsidence in the upper plate thousands of kilometers from the arc front producing regional-scale, generally shallow water depositional settings (e.g. Gurnis, 1992; DeCelles, 2012). The extensive distribution of 1255-1230 Ma shallow marine carbonate sequences throughout southwest Laurentia is therefore consistent with deposition in a retroarc basin setting (Fig. $6 \mathrm{~A}$ cross section).

\subsubsection{0-1180 Ma slab breakoff and subduction reversal}

Continental arc magmatism along the southern margin of Laurentia appears to have ceased by $1232 \mathrm{Ma}$ and was followed by a reversal in subduction zone polarity (Mosher et al., 2008). We speculate that the end of 1255-1230 Ma carbonate sedimentation throughout southwest Laurentia coincided with uplift following slab break off and termination of north-dipping subduction along the southern margin of Laurentia (Fig. 6B). Subduction zone reversal is interpreted to have occurred between 1232 and 1150 Ma based on the absence of magmatism of this age in the Llano uplift (Mosher et al., 2008). However, our data suggest a younger age for slab break off and subduction zone reversal as indicated by the presence of 1180-1200 Ma detrital zircons in the upper Unkar Group (Table 1), which unconformably overlie the Bass Formation (a part of the 1255-1230 Ma retroarc basin system; Figs. 3 and 5). A possible source for 1180-1200 Ma zircons in the upper Unkar Group is the Anorthosite-MagneriteCharnockite-Granite complex in the San Gabriel and Eagle Mountains of California, which was emplaced between 1200 and $1180 \mathrm{Ma}$ (Fig. 1 and section 6.1.1). McLelland et al. (2010b) note that AnorthositeMagnerite-Charnockite-Granite suites form in post- or late-tectonic settings with one plausible mechanism for their generation being asthenospheric upwelling and ponding at the base of the crust 
following slab break off. Slab breakoff along the southern margin of Laurentia at ca. 1200-1180 Ma can explain the shutdown of continental arc magmatism, uplift and erosion of 1255-1230 Ma carbonate sequences, and emplacement of Anorthosite-Magnerite-Charnockite-Granite suites in California, which may have been the source of enigmatic 1180-1200 Ma detrital zircons in the siliciclastic sequences deposited during the next phase of Late Mesoproterozoic sedimentation throughout southwest Laurentia (Fig. 6B).

\subsubsection{0-1100 Ma distal foreland basin sedimentation}

The unconformity above the 1255-1230 Ma carbonate sequences (Fig. 3C) represents a hiatus of at least 40 million years and was followed by deposition of siliciclastic sediments of the upper Unkar Group and correlative units of the Troy Quartzite, Llanoria Formation, and possibly the Las Animas Formation (Fig. 2). The depositional age of these siliciclastic sequences is best constrained in the upper Unkar Group where the Dox Formation has a maximum depositional age of 1140 Ma based detrital mica ages (Table 1 and Timmons et al., 2005) and a minimum depositional age of 1104 Ma from the Cardenas Basalt, which was emplaced during deposition of the upper parts of the Dox Formation (Timmons et al., 2005). The 1140-1100 Ma siliciclastic sequences were deposited in widespread shallow marine and fluvial settings across southwest Laurentia (Fig. 1). Previous correlation of these sequences highlighted lithological similarities, including the presence of soft-sediment deformation features (Shride, 1967; Wrucke, 1989; Seeley, 1999; Timmons et al., 2005). Correlation is further supported by the new detrital zircon dataset, which shows that the siliciclastic sequences typically contain abundant $1600-1800 \mathrm{Ma}$ zircons likely derived from the Yavapai and Mazatzal Provinces, a high proportion of $c a .1450$ Ma detrital zircons sourced from local A-type granite plutons, and 'Grenville-aged' zircons derived from the eroded remnants of the 1288-1232 Ma continental arc along the southern margin of Laurentia or reworked from lower units (Table 1 and Figs. 4 and 5). The 1140-1100 Ma siliciclastic deposits temporally overlap with syn- and post-collisional events in the Llano uplift (1150-1070 Ma) and we interpret these sedimentary units to have been deposited in a series of distal foreland basins during continent-continent collision along the southern margin of Laurentia (Fig. 6C). The lack of 1070-1150 Ma detrital zircon in these distal foreland basin sequences suggests that the high-grade core of the southern Grenville orogen was not extensively exposed between 1140 and1100 Ma. Instead, we suggest the 1140-1100 Ma basins were derived from relatively low-grade rocks in the structurally high parts of the orogen.

The 1140-1100 Ma distal foreland basins of southwest Laurentia have a provenance and sedimentary history that is similar in character to the early phases of sedimentation in foreland basins of the Alpine and Himalayan continent-continent collisions. Foreland basins in the Alps and Himalaya were initially sourced from local basement and low-grade cover sequences imbricated by thrust stacking in the developing orogen, whereas in the later phases of the orogeny, sequences were sourced predominantly from the high-grade core of the orogen (Alps: Sinclair, 1997; Spiegel et al., 2000, Carrapa et al., 2004b, Kuhlemann et al., 2006; Jourdan et al., 2013; Himalaya: DeCelles et al., 1998; 2004, Najman \& Garzanti, 2000, White et al., 2002; Ravikant et al., 2011). The post-collisional stages of foreland basin sedimentation observed from the Alpine and Himalayan orogens are apparently not widely preserved in Late Mesoproterozoic foreland basins of southwest Laurentia with only the Hazel Formation containing abundant detrital zircons (20 out of 94 analyses, Fig. 5) interpreted to be derived from the 1150-1070 Ma high-grade core of the southern Grenville orogen (Fig. 6D, Bickford et al., 2000; Spencer et al., 2014).

Accommodation space in foreland basins is a response to lithospheric flexure driven by loading of thrust nappes onto the upper plate, the effects of which can extend for hundreds of kilometers perpendicular 
to the orogenic front (e.g. DeCelles \& Giles 1996; DeCelles, 2012). These flexural loading effects decrease away from the orogenic front such that distal foreland basin deposits produced by lithospheric flexural alone are predicted to be relatively thin ( $<600 \mathrm{~m}$, DeCelles \& Giles, 1996; DeCelles, 2012). The presence of approximately $2 \mathrm{~km}$ of foreland basin strata in the upper Unkar Group, located some 600 $\mathrm{km}$ from the orogenic front (Fig. 1), therefore requires a mechanism in addition to flexural loading to produce the required accommodation space for Late Mesoproterozoic foreland basin sedimentation in southwest Laurentia.

\subsubsection{0-1100 Ma intracratonic extension and magmatism}

Timmons et al. (2005) interpret syn-sedimentary extensional faulting in the upper Unkar Group to record a regional northeast-southwest extensional regime throughout southwest Laurentia, which developed perpendicular to the orogenic front during continent-continent collision. Syn-orogenic rift basins striking at a high angle to orogenic fronts (i.e. the "Impactogens" of Şengör et al., 1978; Şengör, 1995) are recognized in many collisional settings (e.g. Ingersoll, 2012; Allen et al., 2015) and are interpreted to form in response to extension that is kinematically linked to collision at the plate margin. The most comprehensively studied examples of "Impactogens" related to continent-continent collisions are the late Cenozoic Baikal Rift (Siberia) and the Cenozoic Rhine graben (Europe). The Baikal Rift represents a distal portion of an extensive system of transtentional and transpressional syn-orogenic basins developed throughout the continental interior of Asia during the Himalayan Orogeny (e.g. Molnar \& Tapponnier 1975; Allen et al., 1999; Yin \& Harrison, 2000).The Baikal Rift consists of a series of subbasins with a complex depositional history, the most recent phase of which occurred during the collision of India with Asia in a transtensional setting approximately $3000 \mathrm{~km}$ from the orogenic front (e.g. Polyansky, 2002; Petit \& Déverchère 2006; Mats, 2012; Buslov 2012). The Rhine graben has a similarly complex depositional history associated with transtension related to the Alpine Orogeny and was sourced from basement uplifts adjacent to the rift and more distally from the developing orogen (Şengör, 1978; Sissingh, 1998; Hagedorn \& Boenigk 2008; Reiter et al., 2013, 2015). The structural history, extensive distribution, and provenance of 1140-1100 Ma siliciclastic sequences in southwest Laurentia are therefore similar to analogue "Impactogens" associated with geologically recent continent-continent collisions. We suggest these similarities also highlight the important influence that regional extension driven by continent-continent collision had in the development of Late Mesoproterozoic foreland basins in southwest Laurentia.

\subsubsection{0-1035 Ma proximal foreland basin sedimentation}

The youngest episode of sedimentation associated with the Grenville orogeny in southern Laurentia is recorded by the proximal foreland basin deposits of the Hazel Formation at Van Horn, western Texas (Figs. 1 and 2). The Llanoria Formation in Franklin Mountains of western Texas may also have been deposited during the 1060-1035 Ma deformation in western Texas if correlation with the Hazel Formation is favoured (Spencer et al., 2014). However, we propose an alternative interpretation in which the Llanoria Formation is correlated with the 1140-1100 Ma siliciclastic sequences throughout southwest Laurentia based on the scarcity of <1150 Ma detrital zircons (5 out of 266 analyses, Fig. 5) and minimum depositional age indicated by the overlying $1111 \mathrm{Ma}$ Thunderbird Group and crosscutting $1120 \mathrm{Ma}$ Red Bluff Granite. The Hazel Formation was deposited synchronously with northwest-directed thrusting in the Van Horn region at 1060-1035 Ma (Soegaard \& Callahan, 1994; Bickford et al., 2000; Grimes \& Mosher, 2003; Spencer et al., 2014). The youngest episode of Late Mesoproterozoic deformation at Van Horn is recorded by movement on the frontal thrust of the southern Grenville 
orogen at 1000-980 Ma (Grimes \& Mosher, 2003; Grimes \& Copeland, 2004; Davis \& Mosher, 2015). Deformation in the Van Horn region at 1060-980 Ma therefore post-dates the end of continentcontinent collision in the Llano uplift by at least 60 million years (Bickford et al., 2000; Grimes \& Copeland, 2004; Davis \& Mosher, 2015). Davis \& Mosher (2015) propose that collision of a continent with the southern margin of Laurentia during the Grenville Orogeny first occurred at 1150-1120 Ma in the Llano uplift, while subduction of ocean crust continued in the Van Horn region to the east (Fig. 6C). Closure of the small ocean basin to the east of the Llano uplift lead to clockwise rotation of the colliding continent and eventual collision with the southern margin of Laurentia at 1060-980 Ma in western Texas (Fig. 6D). The sedimentary record of the Hazel Formation is therefore interpreted to reflect continent-continent collision during the final phase of the Grenville Orogeny in southern Laurentia.

\subsection{Comparison with syn-orogenic basins in the northeastern Grenville orogen}

The southern Grenville orogen represents a portion of the larger Grenville orogenic system, which is widely exposed throughout northeast Laurentia in the northeastern United States and eastern Canada (Fig. 1, Rivers, 1997; 2008; Davidson, 1995; 2008). Portions of the Grenville orogen are also exposed in formerly contiguous crust in Scotland (Storey, et al., 2005) and Ireland (Daly \& Flowerdew, 2005). The Sveconorwegian orogen of Norway and Sweden was likely continuous with the Grenville orogen of northeast Laurentia but appears to be a predominantly accretionary orogen and is not considered further here (Bingen et al., 2002; 2008; Slagstad et al., 2013). Sedimentary basins formed during the Grenville Orogeny occur throughout northeastern Laurentia and are well exposed in the foreland of the orogen in Scotland (e.g. Cawood et al., 2007). These basins provide a key record of the Grenville Orogeny in northeast Laurentia as it evolved from a convergent margin dominated by accretionary processes at ca. 1300-1100 Ma to a continent-continent collisional orogen at 1080-980 Ma (Rivers, 1997; 2008; Rivers \& Corrigan, 2000; Gower \& Krogh 2002, Tollo et al., 2004; Cawood et al., 2007; Davidson, 2008; Hynes \& Rivers, 2010). The Late Mesoproterozoic basins of northeast Laurentia and Scotland can be broadly divided into basins formed during the accretionary stages of the Grenville Orogeny prior to continent-continent collision and those formed during continent-continent collision (Cawood et al., 2007; Spencer et al., 2015).

Late Mesoproterozoic basins that formed prior to continent-continent collision in northeastLaurentia comprise ca. 1300-1250 Ma carbonate, siliciclastic, and bimodal volcanic rocks and include the Grenville supergroup and related inliers in the Appalachian orogen (Wynne-Edwards, 1972; Easton, 1992; Chiarenzelli et al., 2015). Similar-aged sequences in Ontario and Labrador include the Simarnekh Formation (Spencer et al., 2015), the western Wakeham Supergroup (Rivers \& Corrigan, 2000), and the Seal Lake Group (van Nostrand \& Lower, 2010). The 1300-1250 Ma volcano-sedimentary successions of northeast Laurentia are interpreted to be back arc and marginal basins deposited inboard of an accretionary margin (Rivers \& Corrigan, 2000). A younger series of predominantly siliciclastic sedimentary sequences were deposited throughout northeast Laurentia at ca. 1150-1090 Ma and include the Flinton Group (Sager-Kinsman \& Parrish, 1993), Twelve Mile quartzite (Wodicka et al., 1996), St. Boniface quartzite (Corrigan \& Van Breeman, 1997), and psammite on Battle Island, Labrador (Kamo et al., 2011). The 1150-1090 Ma basins likely formed in response to extension associated with continued accretionary orogenesis along the eastern margin of Laurentia (Cawood et al., 2007). The 1150-1090 Ma basins contain abundant 1350-1150 Ma detrital zircons, which were likely derived from local arc-related plutons and voluminous Anorthosite-Magnerite-Charnockite-Granite suites, 
consistent with deposition inboard of an accretionary margin (Sager-Kinsman \& Parrish, 1993; Cawood et al., 2007). In Scotland, the 1180 Ma Stoer Group may represent a failed continental rift basin that predates continent-continent collision during Grenville Orogeny (Rainbird et al., 2001; Cawood et al., 2007; Parnell et al., 2011) and was sourced exclusively from local Archean and Paleoproterozoic basement (Rainbird et al., 2001). The provenance of the Stoer Group may indicate the absence of arc-related magmatism in the Scottish sector of the Grenville Orogeny or isolation of the Stoer Group basin from contemporaneous arc sources (Cawood et al., 2007).

The main phase of continent-continent collision in the Grenville Orogeny in northeast Laurentia at 1080-980 Ma was accompanied by deposition of up to $8 \mathrm{~km}$ of predominantly fluvial sediments in the Midcontinent Rift in the Lake Superior region (Craddock et al., 2013; Stein et al., 2015; Malone et al., 2016) and in the East Continent Rift System of Indiana, Kentucky, and Ohio (Santos et al., 2002;

Baranoski et al., 2009). The Midcontinent Rift and East Continent Rift formed in a complex tectonic setting related to both continental rifting and mantle plume activity, which occurred within the foreland of the Grenville orogen (e.g. Hutchinson et al., 1990; Baranoski et al., 2009; Craddock et al., 2013; Bright et al., 2014; Stein et al., 2015; Malone et al., 2016). Sediments deposited during the continent-continent collisional phase of the Grenville Orogeny in Scotland include up to $12 \mathrm{~km}$ of predominantly clastic strata comprising the ca. 1020-980 Ma Torridon, Morar, and Sleat Groups (Stewart, 2002; Kinnaird et al., 2007; Cawood et al., 2007; Krabbendam et al., 2008; 2014; Krabbendam et al., in review). The 1080$980 \mathrm{Ma}$ basins of northeast Laurentia and Scotland likely represent proximal foreland basins formed primarily in response to orogenic loading of the Laurentian margin during continent-continent collision (Rainbird et al., 2001; Kinnaird et al., 2007; Krabbendam et al., in review, but see Williams \& Foden, 2011 for an alternative interpretation).

Episode of basin formation in northeast Laurentia and Scotland at 1300-1250 Ma, 1150-1090 Ma, and 1080-980 Ma, broadly overlap in time with the four phases of Late Mesoproterozoic basin formation in southwest Laurentia. Although similar in age, important differences exist in the tectonic setting of some Late Mesoproterozoic basins in southwest Laurentia compared to those in northeast Laurentia and Scotland. The tectonic setting of the earliest phases of syn-orogenic sedimentation in southwest Laurentia and northeast Laurentia share the closest similarities. The 1300-1250 Ma volcanosedimentary sequences of northeast Laurentia were deposited in back arc or marginal basins, analogous to the tectonic setting inferred for the 1340-1320 Ma Pioneer Shale-lower Crystal Spring Formation and 1255-1230 Ma carbonate sequences of southwest Laurentia. Together, these ca. 1350-1230 Ma sedimentary and volcanic sequences represent a series of back arc and marginal basins developed inboard of an accretionary orogen extending along the entire southern and eastern margins of Laurentia (e.g. Rivers \& Corrigan, 2000; Whitmeyer \& Karlstrom, 2007).

A distinct change in the tectonic setting of the Grenville Orogeny from an accretionary orogen to a collisional orogen is recorded by the foreland basins of southwest Laurentia, northeast Laurentia, and Scotland. Foreland basin deposition was widespread throughout southwest Laurentia at 1140-1100 Ma during the initial stages of continent-continent collision along the margin to the south (Fig. 6C). In contrast, 1150-1090 Ma basins in northeast Laurentia formed in an accretionary orogenic setting that pre-dates continent-continent collision in the northeastern Grenville Orogeny. Continent-continent collision in northeast Laurentia at 1080-980 Ma is recorded by clastic sediments deposited in the Midcontinent Rift and East Continent Rift in the foreland of the Grenville orogen and proximal foreland basin sediments in Scotland. The syn-collisional sedimentary basins in northeast Laurentia and Scotland 
were deposited at the same time as the 1060-1035 Ma proximal foreland deposits of the Hazel Formation in western Texas. Despite similarities in age and tectonic setting, the Hazel Formation formed in response to a different continent-continent collision to time-equivalent sequences in northeast Laurentia and Scotland. The continent-continent collisional phase of the Grenville Orogeny in northeast Laurentia and Scotland records collision of the Amazonia craton with northeast Laurentia (e.g. Hoffman, 1991; Tohver et al., 2006; Li et al., 2008), whereas in southern Laurentia, the colliding block is generally interpreted to be the Kalahari craton (e.g. Dalziel et al., 2000; Li et al., 2008; Ksienzyk \& Jacobs, 2015).

In summary, the Late Mesoproterozoic sedimentary basins of southwest Laurentia, northeast Laurentia, and Scotland are an important record of convergence, accretion, and collision along the southern and eastern margins of Laurentia during the Grenville Orogeny. Late Mesoproterozoic basins in southwest and northeast Laurentia record a shared history of back arc basin sedimentation associated with a convergent margin that extended from southern Laurentia to northeastern Laurentia from ca. 1350$1230 \mathrm{Ma}$ (Whitmeyer \& Karlstrom, 2007). The syn-collisional sedimentary record of Late

Mesoproterozoic basins in southwest Laurentia and northeast Laurentia differs markedly, with foreland basin sedimentation in southwest Laurentia initiating earlier (1140 Ma) than in northeast Laurentia and Scotland (1080 Ma). This contrasting record of Late Mesoproterozoic foreland basin sedimentation reflects the collision of two separate continents at different times and along different segments of the Laurentian margin (e.g. Hoffman, 1991; Li et al., 2008).

\subsection{Paleogeographic Implications}

The Grenville orogen represents one of several Late Mesoproterozoic orogenic belts worldwide that record the assembly of the supercontinent Rodinia. As Laurentia occupied a central position in Rodinia (e.g. Dalziel, 1991; Hoffman, 1991), identifying the extension of the Grenville orogen on formerly adjacent continents is critical for refining the paleogeographic configuration of the supercontinent. One particularly controversial challenge for refining the paleogeographic configuration of Rodinia is identifying the continuation of the southern Grenville orogen into continents formerly to the west of Laurentia (e.g. Moores, 1991; Dalziel, 1991; Karlstrom et al., 1999; 2001; Burrett \& Berry 2001; Sears \& Price, 2000; Wingate et al., 2002; Fioretti et al., 2005; Li et al., 2008; Goodge et al., 2008). Both the southern Grenville orogen and the associated Late Mesoproterozoic syn-orogenic basins are truncated by the western Neoproterozoic rift margin of Laurentia (Fig. 1). Therefore, in addition to matching 'Grenville-aged' magmatic and metamorphic events, identifying possible correlates of the Late Mesoproterozoic basins of southwest Laurentia on formerly contiguous continents will assist in locating the western continuation of the Grenville orogen within Rodinia. The Late Mesoproterozoic basins of southwest Laurentia represent a particularly promising piercing point to test paleogeographic reconstructions of Rodinia as the stratigraphy and provenance of the basins are remarkably consistent across a regionally extensive area.

\subsection{Conclusion}

Detrital zircon, muscovite, and biotite data from Late Mesoproterozoic sequences throughout southwest Laurentia provide a powerful combination of datasets to refine depositional ages, regional correlations, and a better understanding of the tectonic context for this widespread phase of sedimentation. We highlight the episodic nature of basin formation throughout southwest Laurentia during the Late 
Mesoproterozoic, which is characterized by four syn-orogenic basin forming episodes that correspond to different stages of convergence and collision during the Grenville Orogeny in southern Laurentia.

Deposition of 1340-1320 Ma fluvial deposits of the Pioneer Shale and lower member of the Crystal Spring Formation are remnants of a distal back arc basin system development inboard of the southern convergent margin of Laurentia. Following an approximately 70 million year hiatus, the next phase of basin formation is recorded by $1255-1230$ Ma shallow marine carbonate sequences. The $1255-1230$ Ma carbonate sequences contain detrital zircon and muscovite sourced from local Paleoproterozoic and Mesoproterozoic basement and an active continental arc system along the southern margin of Laurentia. These widespread carbonate sequences were deposited in an extensive retroarc basin system that was uplifted and eroded following termination of north-dipping subduction along the southern margin of Laurentia at 1230-1180 Ma. A hiatus of at least 40 million years was followed by shallow marine and terrestrial siliciclastic sedimentation throughout southwest Laurentia at 1140-1100 Ma. The 1140-1100 Ma siliciclastic strata contain detrital zircon and muscovite derived largely from local basement provinces and from the erosion of thrust nappes exhumed during the early stages of continent-continent collision along the southern margin of Laurentia. The 1140-1100 Ma siliciclastic sequences likely represent an extensive foreland basin system developed during the first phase of continent-continent collision during the Grenville Orogeny in southern Laurentia. Accommodation space for the 1140-1100 Ma foreland basins was driven in part by regional intracratonic extension throughout southwest Laurentia driven by continent-continent collision along the margin to the south. The final episode of Late Mesoproterozoic sedimentation in southwest Laurentia is recorded in the Hazel Formation, which was deposited in a proximal foreland basin as continent-continent collision migrated westward along the southern margin of Laurentia.

The Late Mesoproterozoic sedimentary record of southwest Laurentia refines models proposed for the geodynamic evolution of the southern margin of Laurentia during the Mesoproterozoic by providing evidence for an extensive ca. 1300-1230 Ma continental margin arc that pre-dated continent-continent collision. We also revise the timing of the reversal from north-dipping to south-dipping subduction zone polarity along the southern margin of Laurentia to between 1230 and $1180 \mathrm{Ma}$. The combination of detrital mica and detrital zircon data provide a critical dataset for unraveling the unroofing record of structurally high levels of the hinterland of the Grenville orogen in southern Laurentia, which are no longer exposed. The record of Late Mesoproterozoic back arc basin sedimentation in southwest Laurentia at $1340-1320 \mathrm{Ma}$ and $1255-1230 \mathrm{Ma}$ is similar to that preserved in the northeastern sector of the Grenville Orogeny and supports the existence of an extensive accretionary orogen along the southern and eastern margins of Laurentia prior to continent-continent collision. Foreland basin sedimentation in southwest Laurentia initiated at least 60 million years earlier than in northeast Laurentia and Scotland, suggesting the southern and northeastern Grenville orogens record the collision of two different continents with the margin of Laurentia during the Late Mesoproterozoic. Future identification of remnants of the distinctive Late Mesoproterozoic basin system of southwest Laurentia on the continent(s) formerly adjacent to western Laurentia should provide an important piercing point for improving paleogeographic reconstructions of Rodinia. 


\section{Acknowledgements}

We gratefully acknowledge Grand Canyon National Park for permission to undertake research and sampling within Grand Canyon. J. Hagadorn and C. Dehler are thanked for assistance in the field. Field work was supported by NSF grant EAR-1144521 and analytical work at the Arizona LaserChron center is supported by NSF grant EAR-1338583. Mike Doe is thanked for providing unpublished detrital zircon data from the Pioneer Shale. This research was made possible through an Australian Government Endeavour Postgraduate Exchange Scholarship award to J. Mulder. We thank Randy Parrish for editorial handling and Maarten Krabbendam and two anonymous reviews for constructive reviews that improved the manuscript. Maarten Krabbendam is further thanked for insightful comments on the tectonic evolution and sedimentary record of the Grenville Orogeny in Scotland.

\section{References}

Allen, M. B., Vincent, S. J., Wheeler, P. J., 1999. Late Cenozoic tectonics of the Kepingtage thrust zone: interactions of the Tien Shan and Tarim basin, northwest China: Tectonics. 18, 639-654.

Allen, P.A., Eriksson, P.G., Alkmim, F.F., Betts, P.G., Catuneanu, O., Mazumder, R., Meng, Q., Young, G.M., 2015. Classification of basins, with special reference to Proterozoic examples. Precambrian Basins of India: Stratigraphic and Tectonic Context. In Mazumder, R., Eriksson, P.G., (Eds.). Precambrian Basins of India, Stratigraphic and Tectonic Context 5-28.

Amarante, J.F.A., 2001. Characteristic of the basement rocks in the Mescalero 1 well, Guadalupe County, New Mexico [M.S. thesis]. Socorro, New Mexico Institute of Mining and Technology. p. 73.

Ballard, J.L.W., 1997. The depositional history of the Mundy Breccia and lowermost member of the Lanoria Formation. [M.S. Thesis]. El Paso, University of Texas. p. 360.

Baranoski, M., Dean, S., Wicks, J., Brown, V., 2009. Unconformity-bounded seismic reflection sequences define Grenville-age rift system and foreland basins beneath the Phanerozoic in Ohio. Geosphere. 5, 140-151.

Barnes, M.A., 2001. The Petrology and Tectonics of the Mesoproterozoic margin of southern Laurentia. [PhD Thesis]. Lubbock, Texas Tech University. p. 287.

Barth, A.P., Wooden, J.L., Coleman, D.S., 2001. SHRIMP-RG U-Pb zircon geochronology of Mesoproterozoic metamorphism and plutonism in the southwesternmost United States. Journal of Geology. 109 (3), 319-327.

Beaumont, C., 1981. Foreland basins. Geophysical Journal International. 65, 291-329.

Beraldi-Campesi, H., Farmer, J.D., Garcia-Pichel. F., 2014. Modern Terrestrial Sedimentary Biostructures and Their Fossil Analogs in Mesoproterozoic Subaerial Deposits. Palaios. 29, 45-54.

Bertrand-Sarfati, J., Awramik, S.M., 1992. Stromatolites of the Mescal Limestone (Apache Group, Middle Proterozoic, Central Arizona) - Taxonomy, Biostratigraphy, and Paleoenvironments. Geological Society of America Bulletin. 104, 1138-1155.

Bickford, M.E., Soegaard, K., Nielsen, K.C., and McLelland, J.M., 2000. Geology and geochronology of Grenville- age rocks in the Van Horn and Franklin Mountains area, west Texas; implications for the tectonic evolution of Laurentia during the Grenville: Geological Society of America Bulletin. 112, 1134-1148. 
Bickford, M.E., Van Schmus, W.R., Karlstrom, K.E., Mueller, P.A., Kamenov, G.D., 2015. Mesoproterozoic-transLaurentian magmatism: A synthesis of continent-wide age distributions, new SIMS U-Pb ages, zircon saturation temperatures, and Hf and Nd isotopic compositions. Precambrian Research. 265, 286-312.

Bingen, B., Mansfield, J., Sigmond, E.M.O., Stein, H., 2002. Baltica-Laurentia link during the Mesoproterozoic: 1.27 Ga development of continental basins in the Sveconorwegian Orogen, southern Norway. Canadian Journal of Earth Sciences. 39, 1425-1440.

Bingen, B., Andersson, J., Söderlund, U., Möller, C., 2008. The Mesoproterozoic in the Nordic countries. Episodes. $31,29-34$.

Bowring, S.A., Karlstrom, K.E., 1990. Growth, stabilization, and reactivation of Proterozoic lithosphere in the southwestern United States: Geology. 18, 1203-1206

Bright, R.M., Amato, J.M., Denyszyn, S.W., Ernst, R.E., 2014. U-Pb geochronology of 1.1 Ga diabase in the southwestern United States: Testing models for the origin of a post-Grenville large igneous province. Lithosphere. 6, 135-156.Burrett, C., Berry, R., 2000. Proterozoic Australia-Western United States (AUSWUS) fit between Laurentia and Australia: Geology. 28, 103-106.

Buslov, M.M., 2012. Geodynamic nature of the Baikal Rift Zone and its sedimentary filling in the CretaceousCenozoic: the effect of the far-range impact of the Mongolo-Okhotsk and Indo-Eurasian collisions. Russian Geology and Geophysics. 53, 955-962.

Burns, B.A., 1987. The sedimentology and significance of a Middle Proterozoic braidplain; Chediski sandstone member of the Troy Quartzite, central Arizona. [M.S. thesis]. Flagstaff, Northern Arizona University. p. 143.

Carlson, W.D., Anderson, S.D., Mosher, S., Davidow, J.S., Crawford, W.D., Lane, E.D., 2007. High-pressure metamorphism in the Texas Grenville orogen: Mesoproterozoic subduction of the southern Laurentian continental margin: International Geology Review. 49, 99-119.

Carrapa, B., Di Giulio, A., Wijbrans, J., 2004a. The early stages of the Alpine collision: an image derived from the upper Eocene-lower Oligocene record in the Alps-Apennines junction area. Sedimentary Geology. 171, 181-203.

Carrapa, B., Wijbrans, J., Bertotti, G., 2004b. Detecting provenance variations and cooling patterns within the western Alpine orogen through ${ }^{40} \mathrm{Ar} /{ }^{39} \mathrm{Ar}$ geochronology on detrital sediments: The Tertiary Piedmont Basin, northwest Italy. In Bernet, M., and Spiegel, C., (Eds.), Detrital thermochronology-Provenance analysis, exhumation, and landscape evolution of mountain belts: Boulder, Colorado, Geological Society of America Special Paper 378.

Cawood, P.A., Nemchin, A.A., Strachan, R., Prave, T., Krabbendam, M., 2007. Sedimentary basin and detrital zircon record along East Laurentia and Baltica during assembly and breakup of Rodinia. Journal of the Geological Society, London. 164, 257-275.

Chiarenzelli, J., Kratzmann, D., Selleck, B., deLorraine, W., 2015. Age and provenance of Grenville supergroup rocks, Trans-Adirondack Basin, constrained by detrital zircons. Geology. 43 (2), 183-186.

Corrigan, D. and van Breemen, O., 1997. U-Pb age constraints for the lithotectonic evolution of the Grenville Province along the Mauricie transect, Quebec. Canadian Journal of Earth Sciences. 34, 299-316.

Cullom, C.R., 1996. Sedimentology and petrology of the Pioneer Formation, middle Proterozoic, central Arizona [M.S. thesis]. Flagstaff, Northern Arizona University. p. 120. 
Dalton, R.O., Jr., 1972. Stratigraphy of the Bass Formation (Late Precambrian, Grand Canyon, Arizona) [M.S. thesis]. Flagstaff, Northern Arizona University. p. 140.

Daly, J.S., Flowerdew, M.J., 2005. Grampian and late Grenville events recorded by mineral geochronology near a basement-cover contact in north Mayo, Ireland Journal of the Geological Society. 162, 163-174.

Daneker, T.M., 1975. Sedimentology of the Precambrian Shinumo Sandstone, Grand Canyon, Arizona [M.S. thesis]. Flagstaff, Northern Arizona University. p. 195.

Daniel, C.G., Pfeifer, L.S., Jones, J.V., III, McFarlane, C.M., 2013. Detrital zircon evidence for non-Laurentian provenance, Mesoproterozoic (ca. 1490-1450 Ma) deposition and orogenesis in a reconstructed orogenic belt, northern New Mexico, USA: Defining the Picuris orogeny: Geological Society of America Bulletin. 125 (9-10), 14231441.

Daniel, C.G., Pyle, J.M., 2006, Monazite-xenotime thermo- chronometry and $\mathrm{Al}_{2} \mathrm{SiO}_{5}$ reaction textures in the Picuris Range, northern New Mexico, USA: New evidence for a 1450-1400 Ma orogenic event: Journal of Petrology. 47 (1), 97-118.

Davidson, A., 1995, A review of the Grenville orogen in its North American type area: Journal of Australian Geology and Geophysics. 16, 3-24.

Davidson, A., 2008. Late Paleoproterozoic to mid-Neoproterozoic history of northern Laurentia; an overview of central Rodinia. Precambrian Research. 160, 5-22.

Davis, B.R., Mosher, S. 2015. Complex structural and fluid flow evolution along the Grenville Front, west Texas. Geosphere. 11, 868-898.

Dalziel, I.W.D., 1991. Pacific margins of Laurentia and East Antarctica-Australia as a conjugate rift pair: Evidence and implications for an Eocambrian supercontinent: Geology. 19, 598-601

Dalziel, I.W.D., Mosher, S., Gahagan, L. M., 2000, Laurentia-Kalahari collision and the assembly of Rodinia: Journal of Geology. 108, 499-513.

DeCelles, P. G., Giles, K.N. 1996. Foreland basin systems. Basin Research. 8, 105- 123.

DeCelles, P.G. 2012. Foreland basin systems revisited: variations in response to tectonic settings. In Busby, C. J., Azor, A., (Eds.). Tectonics of Sedimentary Basins: Recent Advances, 2nd edition. Wiley-Blackwell, Oxford. p. 405426. DeCelles, G., Giles, K.N., 1996. Foreland basin systems. Basin Research. 8, 105-123.

DeCelles, G., Gehrels, G.E., Quade, J., Ojha, T.P., 1998. Eocene-early Miocene foreland basin development and the history of Himalayan thrusting, western and central Nepal. Tectonics. 17, 741-765.

DeCelles, P.G., Gehrels, G.E., Najman, Y., Martin, A.J., Carter, A., Garzanti, E., 2004. Detrital geochronology and geochemistry of Cretaceous-Early Miocene strata of Nepal: implications for timing and diachroneity of initial Himalayan orogenesis. Earth and Planetary Science Letters. 227, 313-330.

Doe, M.F., 2014, Reassessment of Paleo- and Mesoproterozoic Basin Sediments of Arizona: Implications for Tectonic Growth of Southern Laurentia and Global Tectonic Configurations [Ph.D. Thesis]. Golden, Colorado, Colorado School of Mines. p. 649. 
Doe, M.F., Jones, J.V., Karlstrom, K.E., Thrane, K., Frei, D., Gehrels, G., Pecha, M., 2012. Basin formation near the end of the 1.60-1.45 Ga tectonic gap in southern Laurentia: Mesoproterozoic Hess Canyon Group of Arizona and implications for ca. 1.5 Ga supercontinent configurations: Lithosphere. 4 (1), 77-88.

Doe, M.F., Jones, J. V., Karlstrom, K.E., Dixon, B., Gehrels, G., Pecha, M., 2013. Using detrital zircon ages and Hf isotopes to identify $1.48-1.45 \mathrm{Ga}$ sedimentary basins and fingerprint sources of exotic $1.6-1.5 \mathrm{Ga}$ grains in southwestern Laurentia: Precambrian Research. 231, 409-421.

Duebendorfer, E. M. 2015. Refining the Early History of the Mojave-Yavapai Boundary Zone: Rifting versus Arc Accretion as Mechanisms for Paleoproterozoic Crustal Growth in Southwestern Laurentia. Journal of Geology. 123, 21-37.

Easton, R.M., 1992. The Grenville Province and the Proterozoic history of central and southern Ontario. In Thurston, P.C., (Ed.), Geology of Ontario: Ontario Geological Survey Special Volume 4, Part 2, 714-964.

Edwards, G., 1984. Petrography and geochemistry of the Allamoore Formation, Culberson and Hudspeth counties, Texas [Ph.D. Thesis]. University of Texas at El Paso. p. 284.

Engel, M.H., Elmore, R.D., 1990. Assessments of the Hydrocarbon Generation Potential of Selected North American Proterozoic Rock Sequences: Progress report for the U.S. Department of Energy, Grant Number DE-FGO589ERI4075.

Fioretti, A.M., Black, L.P., Foden, J., Visona, D., 2005. Grenville-age magmatism at the South Tasman Rise (Australia): a new piercing point for the reconstruction of Rodinia. Geology. 33, 769-772.

Flawn, P.T., 1956. Basement Rocks of Texas and Southeast New Mexico: The University of Texas Publication number 5605, p. 261.

Fletcher, K. E., 2004, Geochronology and provenance of four Mesoproterozoic basins across the southwest United States: Evidence from ${ }^{40} \mathrm{Ar} /{ }^{39} \mathrm{Ar}$ dating of detrital muscovite [M.S. thesis]. Socorro, New Mexico, New Mexico Institute of Mining and Technology. p. 277.

Garzanti, E., Vezzoli, G., Lombardo, B., Ando, S., Mauri, E., Monguzzi, S. Russo, M. 2004. Collision-orogen provenance (Western Alps): Detrital signatures and unroofing trends. Journal of Geology. 112, 145-164.

Gehrels, G.E., Valencia, V.A., Ruiz, J., 2008, Enhanced precision, accuracy, efficiency, and spatial resolution of U-Pb ages by laser ablation-multicollector-inductively coupled plasma mass spectrometry: Geochemistry Geophysics Geosystems. 9.

Gehrels, G., Pecha, M., 2014. Detrital zircon U-Pb geo- chronology and Hf isotope geochemistry of Paleozoic and Triassic passive margin strata of western North America: Geosphere. 10 (1), 49-65

Goodge, J.W., Vervoort, J.D., 2006. Origin of Mesoproterozoic A-type Granites in Laurentia: Hf isotope evidence: Earth and Planetary Science Letters. 243, 711-731.

Goodge, J.W., Vervoort, J.D., Fanning, C. M., Brecke, D.M., Farmer, G.L., Williams, I.S., Myrow, P.M., DePaolo, D.J., 2008. A positive test of East Antarctica-Laurentia juxtaposition within the Rodinia supercontinent. Science. 321 , 235-240.

Gower, C.F., Krogh, T.E., 2002. A U-Pb geochronological review of the Proterozoic history of the eastern Grenville Province. Canadian Journal of Earth Sciences. 39, 795-829. 
Grimes, S.W., Mosher, S., 2003. Structure of the Carrizo Mountain Group, southeastern Carrizo Mountains, west Texas: A transpressional zone of the Grenville orogeny: Tectonics, 3-1-3-20.

Grimes, S.W., Copeland, P., 2004. Thermochronology of the Grenville Orogeny in west Texas: Precambrian Research. 131, 23-54.

Guitreau, M., Mukasa, S.B., Blichert-Toft, J., Fahnestock, M.F., 2016. Pikes Peak batholith (Colorado, USA) revisited: A SIMS and LA-ICP-MS study of zircon U-Pb ages combined with solution $\mathrm{Hf}$ isotopic compositions. Precambrian Research. 280, 179-194.

Gurnis, M. 1992. Rapid continental subsidence following the initiation and evolution of subduction. Science. 255, 1556-1558.

Hagedorn, E.M., Boenigk, W., 2008. The Pliocene and Quaternary sedimentary and fluvial history in the Upper Rhine Graben based on heavy mineral analyses. Netherlands Journal of Geosciences. 87, 21-32.

Hammond, J.G., 1990. Middle Proterozoic diabase intrusions in the southwestern U.S.A. as indicators of limited extensional tectonism, in Gower, C.F., Rivers, T., Ryan, B., ed., Mid-Proterozoic Laurentia-Baltica: Geological Association of Canada Special Paper 38. p. 517-531.

Harrison, M.T., Duncan, I., McDougall, I., 1985. Diffusion of 40Ar in biotite: Temperature, pressure and compositional effects. Geochimica et Cosmochimica Acta. 49 (11), 2461-2468.

Heaman, L.M., Grotzinger, J.P., 1992, 1.08 Ga diabase sills in the Pahrump Group, California: Implications for development of the Cordilleran miogeocline: Geology. 20, 637-640

Hendricks, J.D., 1972. Younger Precambrian basaltic rocks of the Grand Canyon, Arizona [M.S. thesis]. Flagstaff, Northern Arizona University. p. 122.

Hoffman, P.F., 1988. United Plates of America, the birth of a Craton: Early Proterozoic assembly and growth of Laurentia. Annual Review of Earth and Planetary Science. 16, 543-603.

Hoffman, P.F., 1991. Did the breakout of Laurentia turn Gondwanaland inside out?: Science. 252, 1409-1412.

Holland, M.E., Karlstrom, K.E., Doe, M.F., Gehrels, G.E., Pecha, M., Shufeldt, O.P., Begg, G., Griffin, W.L., Belousova, E. 2015. An imbricate midcrustal suture zone: The Mojave-Yavapai Province boundary in Grand Canyon, Arizona. Geological Society of America Bulletin. 127, 1391-1410.

Howard, K.A., 1991. Intrusion of horizontal dikes: Tectonic significance of Middle Proterozoic diabase sheets widespread in the upper crust of the southwestern United States: Journal of Geophysical Research. 96, 12461- 12478.

Hutchinson, D.R., White, R.S., Cannon, W.F., Schulz, K.J., 1990. Keweenaw hot spot: Geophysical evidence for a 1.1 Ga mantle plume beneath the Midcontinent rift system. Journal of Geophysical Research. 95, 1086910884.

Hynes, A., and Rivers, T., 2010. Protracted continental collision-Evidence from the Grenville orogen. Canadian Journal of Earth Sciences. 47, 591-620.

Ingersoll, R.V., 2012. Tectonics of sedimentary basins, with revised nomenclature. In Busby, C. J. Azor, A. (Eds.), Tectonics of Sedimentary Basins, 2nd edition. Wiley-Blackwell, Oxford. p. 3-43. 
Jones, J.V., Connelly, J.N., Karlstrom, K.E., Williams, M.L., Doe, M.F., 2009. Age, provenance, and tectonic setting of Paleoproterozoic quartzite successions in the southwestern United States: Geological Society of America Bulletin. $121(1-2), 247-264$.

Jones, J.V., Daniel, C.G., Frei, D., Thrane, K., 2011. Revised regional correlations and tectonic implications of Paleoproterozoic and Mesoproterozoic metasedimentary rocks in northern New Mexico, USA: New findings from detrital zircon studies of the Hondo Group, Vadito Group, and Marqueñas Formation. Geosphere. 7 (4), $974-991$.

Jones, J. V., Daniel, C. G., Doe, M. F., 2015. Tectonic and sedimentary linkages between the Belt-Purcell basin and southwestern Laurentia during the Mesoproterozoic, ca. 1.60-1.40 Ga. Lithosphere. 7, 465-472.

Jourdan, S., Bernet, M., Tricart, P., Hardwick, E., Paquette, J. L., Guillot, S., Dumont, T., Schwartz, S., 2013. Shortlived, fast erosional exhumation of the internal western Alps during the late early Oligocene: Constraints from geothermochronology of pro- and retro-side foreland basin sediments. Lithosphere. 5, 211-225.

King, P.B., Flawn, P.T., 1953. Geology and mineral deposits of Precambrian rocks of the Van Horn area, Texas. University of Texas Bureau of Economic Geology Bulletin. 5301, 218.

Kamo, S.L., Heaman, L.M., Gower, C.F., 2011. Evidence for post-1200 Ma - pre-Grenvillian supracrustal rocks in the Pinware terrane, eastern Grenville Province at Battle Harbour, Labrador. Canadian Journal of Earth Sciences. 48, 371-387.

Karlstrom, K.E., Bowring, S.A., 1988. Early Proterozoic assembly of tectonostratigraphic terranes in south- western North America: Journal of Geology. 96, 561-576.

Karlstrom, K.E., Bowring, S.A., 1993. Proterozoic orogenic history in Arizona. In Reed, J.C., Jr., et al., (Eds.), Precambrian: Conterminous U.S. : Boulder, Colorado, Geological Society of America, Geology of North America, v. C-2. p. 188-211.

Karlstrom, K.E., Humphreys, G., 1998. Influence of Proterozoic accretionary boundaries in the tectonic evolution of western North America: Interaction of cratonic grain and mantle modification events: Rocky Mountain Geology. 33, 161-179.

Karlstrom, K.E., Harlan, S.S., Williams, M.L., McLelland, J., Geissman, J.W., and Ahall, K.I., 1999, Refining Rodinia: Geologic evidence for the Australia - Western U.S. connection for the Proterozoic: GSA Today, 9 (10), 1-7.

Karlstrom, K.E., Ahall, K.I., Harlan, S.S., William, M.L., McLelland, J., Geissman, J.W., 2001. Long-lived (1.8-0.8 Ga) convergent orogen in southern Laurentia, its extensions to Australia and Baltica, and implications for refining Rodinia: Precambrian Research. 111, 5-30.

Karlstrom, K.E., Amato, J.M., Williams, M.L., Heizler, M., Shaw, C.A., Read, A.S., Bauer, P., 2004. Proterozoic tectonic evolution of the New Mexico region. In Mack, G.H., Giles, K.A., (Eds.). The geology of New Mexico: A geological history: New Mexico Geological Society Special Publication 11, p. 1-34.

Karlstrom, K.E., Williams, M.L., Heizler, M.T., Holland, M.E., Grambling, T.A., and Amato, J.M., 2016 U-Pb monazite and ${ }^{40} \mathrm{Ar} /{ }^{39} \mathrm{Ar}$ data supporting polyphase tectonism in the Manzano Mountains: a record of both the Mazatzal (1.66-1.60 Ga) and Picuris (1.45 Ga) orogenies. In The Geology of the Belen Area. Frey, B, A.; Karlstrom, K.E., Lucas, S.G., Williams, S., Zeigler, K., McLemore, V., Ulmer-Scholle, D.S (Eds.). New Mexico Geological Society, Guidebook, 67th Field Conference, 177-184. 
Kinnaird, T., Prave, A.R., Horstwood, M., Parrish, R.R., 2007. The late Mesoproterozoic-Early Neoproterozoic tectonostratigraphic evolution of Northwest Scotland: the Torridonian revisited. Journal of the Geological Society, London. 164, 541-551.

Krabbendam, M., Prave, A.P., Cheer, D., 2008. A fluvial origin for the Neoproterozoic Morar Group, NW Scotland; implications for Torridon-Morar group correlation and the Grenville Orogen Foreland Basin. Journal of the Geological Society of London. 165, 379-394.

Krabbendam, M., Leslie, A.G., Goodenough, K.M., 2014. Structure and stratigraphy of the Morar Group in Knoydart, NW Highlands: implications for the history of the Moine Nappe and stratigraphic links between the Moine and Torridonian successions. Scottish Journal of Geology. 50, 125-142.

Krabbendam, M., Bonsor, H., Horstwood, M.S.A., Rivers, T. Tracking the evolution of the Grenvillian Foreland Basin: constraints from sedimentology and detrital zircon and rutile in the Sleat and Torridon groups, Scotland. In Review. Precambrian Research.

Ksienzyk, A. K., Jacobs, J., 2015. Western Australia-Kalahari (WAlahari) connection in Rodinia: Not supported by U$\mathrm{Pb}$ detrital zircon data from the Maud Belt (East Antarctica) and the Northampton Complex (Western Australia): Precambrian Research. 259, 207-221.

Kuhlemann, J., Dunkl, I., Brugel, A., Spiegel, C., Frisch, W., 2006. From source terrains of the Eastern Alps to the Molasse Basin: Detrital record of non-steady-state exhumation. Tectonophysics. 413, 301-316.

Larson, E.E., Patterson, P.E., and Mutschler, F.E., 1994. Lithology, chemistry, age, and origin of the Proterozoic Cardenas Basalt, Grand Canyon, Arizona. Precambrian Research. 65 (1-4), 255-276

Levine, J.S.F., and Mosher, S., 2010. Contrasting Grenville-age tectonic histories across the Llano Uplift,Texas: New evidence for deep-seated high-temperature deformation in the western uplift. Lithosphere. 2, 399-410.

Li, Z.X., Bogdanova, S.V., Collins, A.S., Davidson, A., De Waele, B., Ernst, R.E., Fitzsimons, I.C.W., Fuck, R.A., Gladkochub, D.P., Jacobs, J., Karlstrom, K.E., Lu, S., Natapov, L.M., Pease, V., Pisarevsky, S.A., Thrane, K., Vernikovsky, V., 2008. Assembly, configuration, and break-up history of Rodinia: A synthesis: Precambrian Research. 160, 179-210

Link, P. K., Stewart, E. D., Steel, T., Sherwin, J-A., Hess, L. T., and McDonald, C., 2016. Detrital zircons in the Mesoproterozoic upper Belt Supergroup in the Pioneer, Beaverhead and Lemhi Ranges, Montana and Idaho: The Big White arc. In Maclean J.S, and Sears, J.W. (Eds)., Belt Basin: Window to Mesoproterozoic Earth. Geological Society of America Special Paper 522. 163-183.

Ludwig, K.R., 2003, Isoplot 3.00: A geochronological toolkit for Microsoft Excel: Berkeley, California, Berkeley Geochronological Centre Special Publication 4, p. 74.

Mahon, R.C., Dehler, C.M., Link, P.K., Karlstrom, K.E., Gehrels, G.E. 2014. Detrital zircon provenance and paleogeography of the Pahrump Group and overlying strata, Death Valley, California. Precambrian Research. 251, 102-117.

Malone, D.H., Stein, C.A., Craddock, J.P., Kley, J., Stein, S., Malone, J.E., 2016. Maximum depositional age of the Neoproterozoic Jacobsville Sandstone, Michigan: Implications for the evolution of the Midcontinent Rift: Geosphere. 12 (4), 1-12. 
Mats, V.D. 2012. The sedimentary fill of the Baikal Basin: Implications for rifting age and geodynamics. Russian Geology and Geophysics. 53, 1382-1383.

McConnell, R.L., 1975. Biostratigraphy and depositional environment of algal stromatolites from the Mescal Limestone (Proterozoic) of central Arizona: Precambrian Research. 2, 317-328.

Mclelland, J.M., Selleck, B.W., Bickford, M.E. 2010a. Review of the Proterozoic evolution of the Grenville Province, its Adirondack outlier, and the Mesoproterozoic inliers of the Appalachians. From Rodinia to Pangea: The Lithotectonic Record of the Appalachian Region, 20. p. 21-49.

McLelland, J.M., Selleck, B.W., Hamilton, M.A., Bickford, M.E., 2010b, Late- to post-tectonic setting of some major Proterozoic anorthosite-mangerite-charnockite-granite (AMCG) suites. Canadian Mineralogist. 48, 729-750

Middleton, L.T., Blakey, R.C., 1998. Seismically induced liquefaction in late Proterozoic strata, northern and central Arizona; implications for tectonic setting and regional correlations: Geological Society of America Abstracts with Programs. 30 (2), p. 399.

Middleton, L. T., Trujillo, A. P., 1984. Sedimentology and depositional setting of the upper Proterozoic Scanlan Conglomerate, central Arizona. In Koster, E. H., and Steel, R. H., (Eds.), Sedimentology of gravels and conglomerates. Canadian Society of Petroleum Geologists Memoir 10, 189-201.

Middleton, L.T., Montgomery, M.W., 2001. Sedimentary responses to changing tectonic patterns, Mesoproterozoic Apache Group/Troy Quartzite, Central Arizona, in Rocky Mountain (53rd) and South-Central (35th) Sections, Geological Society of America, Joint Annual Meeting; April 29-May 2, 2001; Albuquerque, New Mexico, Session No. 11.

Mitrovica, J.X., Beaumont, C., Jarvis, G.T., 1989. Tilting of continental interiors by the dynamical effects of subduction: Tectonics. 8, 1079-1094.

Molnar, P., Tapponnier, P., 1975. Cenozoic tectonics of Asia: effects of a continental collision: Science. 189, 419426.

Moores, E.M., 1991, The Southwest U.S.-East Antarctica (SWEAT) connection: A hypothesis. Geology. 19, $425-428$.

Mosher, S., 1998. Tectonic evolution of the southern Laurentian Grenville orogenic belt: Geological Society of America Bulletin. 110, 1357-1375

Mosher, S., Levine, J.S.F., Carlson, W.D., 2008. Mesoproterozoic plate tectonics: A collisional model for the Grenville-aged orogenic belt in the Llano uplift, central Texas: Geology. 36, 55-58

Najman, Y. \& Garzanti, E. 2000. Reconstructing early Himalayan tectonic evolution and paleogeography from Tertiary foreland basin sedimentary rocks, northern India. Geological Society of America Bulletin. 112, 435-449.

Nyman, M.W., Karlstrom, K.E., Kirby, E., Graubard, C., 1994. 1.4 Contractional orogeny in western North America: Evidence from ca. 1.4 Ga plutons: Geology. 22, 901-904

Parnell, J., Mark, D., Fallick, T.E., Boyce, A., Thackrey, S., 2011. The age of the Mesoproterozoic Stoer Group sedimentary and impact deposits, NW Scotland. Journal of the Geological Society of London. 168, 349-358.

Petit, C., Déverchère, J., 2006. Structure and evolution of the Baikal rift: a synthesis. Geochemisty, Geophysics, 
Geosystems. 7.

Pittenger, M.A., Marsaglia, K.M., Bickford, M.E., 1994. Depositional history of the Middle Proterozoic Castner Marble and basal Mundy Breccia, Franklin Mountains, west Texas. Journal of Sedimentary Research. B64, $282-297$.

Polyansky, O.P. 2002. Dynamic causes for the opening of the Baikal Rift Zone: a numerical modelling approach. Tectonophysics. 351, 91-117.

Purdy, J., Jäger, E., 1976, K-Ar ages on rock- forming minerals from the central Alps, Memorie degli Istituti di Geologia e Mineralogia dell' Uni- versità di Padova. 30, 31.

Rainbird, R.H., Hamilton, M.A., Young, G.M., 2001. Detrital zircon geochronology and provenance of the Torridonian, NW Scotland. Journal of the Geological Society, London. 158, 15-27.

Ravikant, V., Wu, F. Y., Ji, W.Q., 2011. U-Pb age and Hf isotopic constraints of detrital zircons from the Himalayan foreland Subathu sub-basin on the Tertiary palaeogeography of the Himalaya. Earth and Planetary Science Letters. 304, 356-368.

Reiter W, Elfert S, Bernet M, Glotzbach C, Spiegel C., 2013. Relations between denudation, glaciation, and sediment deposition: implications from the Plio-Pleistocene Central Alps. Basin Research. 25, 1-16

Reiter, W., Elfert, S., Glotzbach, C., Spiegel, C., 2015. Plio-Pleistocene evolution of the north Alpine drainage system: new constraints from detrital thermochronology of foreland deposits. International Journal of Earth Sciences. 104, 891-907.

Reed, V.S., 1976. Stratigraphy and depositional environ- ment of the upper Precambrian Hakatai Shale, Grand Canyon, Arizona [M.S. thesis]. Flagstaff, Northern Arizona University. p. 163.

Reese, J.S., Mosher, S., Connelly, J., Roback, R., 2000. Mesoproterozoic chronostratigraphy of the southeastern Llano Uplift, central Texas: Geological Society of America Bulletin. 112, 278-291

Reese, J.F., Mosher, S., 2004. Kinematic constraints on Rodinia reconstructions from the core of the Texas Grenville orogen: Journal of Geology. 112, 185-205.

Rivers, T., 1997. Lithotectonic elements of the Grenville province: Review and tectonic implications: Precambrian Research. 86, 117-154.

Rivers, T., 2008. Assembly and preservation of lower, mid, and upper orogenic crust in the Grenville ProvinceImplications for the evolution of large hot long-duration orogens. Precambrian Research. 167, $237-259$.

Rivers, T. and Corrigan, D., 2000. Convergent margin on southeastern Laurentia during the Mesoproterozoic: tectonic implications. Canadian Journal of Earth Sciences. 37, 359-383.

Roback, R.C., 1996. Characterization and tectonic evolution of a Mesoproterozoic island arc in the southern Grenville Orogen, Llano uplift, central Texas: Tectonophysics. 265, 29-52.

Roberts, M.T., 1982. Depositional environments and tectonic setting of the Crystal Spring Formation, Death Valley, California. In: Cooper, J.D., Troxel, B.W., Wright, L.A. (Eds.), Geology of selected areas in the San Bernardino Mountains, Western Mojave Desert, and southern Great Basin, California: Volume and guidebook for field trip no. 9, 78th Anniversary Meeting of Cordilleran Section, Geological Society of America. Death Valley Publishing Company, Shoshone, CA. p. 165-170. 
Ross, G.M., Villeneuve, M.E., 2003. Provenance of the Mesoproterozoic (1.45 Ga) Belt basin (western North America): Another piece in the pre-Rodinia paleogeographic puzzle: Geological Society of America Bulletin. 115, 1191-1217.

Roths, P.J., 1993. Geochemical and geochronological studies of the Grenville-age (1,250-1,000 Ma) Allamoore and Hazel Formations, Hudspeth and Culberson counties, west Texas, In Soegaard, K., et al., (Eds.), Precambrian Geology of the Franklin Mountains and Van Horn Area, Trans-Pecos Texas: Dallas, Texas, Geological Society of America South Central Section, University of Texas. p. 11-35.

Rougive, J.R., Carlson, W.D., Connelly, J.N., Roback, R.C., Copeland, P., 1996. Late thermal evolution of Proterozoic rocks in the northeastern Llano uplift, central Texas: Geological Society of America Abstracts with Programs. 28 (7), p. A376.

Sager-Kinsman, E.A. and Parrish, R.R., 1993. Geochronology of detrital zircons from the Elzevir and Frontenac terranes, Central Metasedimentary Belt, Grenville Province, Ontario. Canadian Journal of Earth Sciences. 30,465473.

Sambridge, M.S., Compston, W., 1994. Mixture modeling of multi-component data sets with application to ionprobe zircon ages: Earth and Planetary Science Letters. 128, 373-390.

Santos, J.O.S., Hartmann, L.A., McNaughton, N.J., Easton, R.M., Rea, R.G., Potter, P.E., 2002. Sensitive high resolution ion microprobe (SHRIMP) detrital zircon geochronology provides new evidence for a hidden Neoproterozoic foreland basin to the Grenville Orogen in the eastern Midwest, USA. Canadian Journal of Earth Sciences. 39, 1505-1515.

Shride, A.F., 1967. Younger Precambrian geology in southern Arizona: U.S. Geological Survey Professional Paper 566. p. 88.

Sears, J.W., 1973, Structural geology of the Precambrian Grand Canyon Series, Arizona [M.S. thesis]. Laramie, University of Wyoming. p. 112.

Sears, J.W., Price, R.A., 2000. New look at the Siberian connection: No SWEAT: Geology. 28, 423-426

Şengör, A.M.C., 1995. Sedimentation and tectonics of fossil rifts, in Busby, C.J., and Ingersoll, R.V., (Eds.), Tectonics of sedimentary basins. Oxford, Blackwell Science. p. 53-117.

Şengör, A.M.C., Burke, K., Dewey, J.F., 1978. Rifts at high angles to orogenic belts; tests for their origin and the Upper Rhine Graben as an example: American Journal of Science. 278 (1), 24-40.

Seeley, J., 1999. Studies of the Proterozoic tectonic evolution of the southwestern United States [Ph.D. thesis]. El Paso, University of Texas, p. 321.

Shannon, W.M., Barnes, C.G., Bickford, M.E., 1997. Grenville magmatism in west Texas: Petrology and geochemistry of the Red Bluff granite suite: Journal of Petrology. 38, 1279-1305.

Shaw, C.A., Heizler, M.T., Karlstrom, K.E., $2005 .{ }^{40} \mathrm{Ar} /{ }^{39} \mathrm{Ar}$ thermochronologic record of $1.45-1.35 \mathrm{Ga}$ 
intracontinental tectonism in the southern Rocky Mountains: Interplay of conductive and advective heating with intracontinental deformation. In Kalstrom, K.E., and Keller, G.R., (Eds.), The Rocky Mountain Region: An Evolving Lithosphere; Tectonics, Geochemistry, and Geophysics. American Geophysical Union Geophysical Monograph 154. 163-184.

Shufeldt, O.P., Karlstrom, K.E., Gehrels, G.E., Howard, K.E., 2010. Archean detrital zircons in the Proterozoic Vishnu Schist of the Grand Canyon, Arizona: Implications for crustal architecture and Nuna supercontinent reconstructions. Geology. 38 (12), 1099-1102.

Sinclair, H.D., 1997. Tectonostratigraphic model for underfilled peripheral foreland basins: an Alpine perspective. Geological Society of America Bulletin. 109, 324-346.

Sissingh, W., 1998. Comparative tertiary stratigraphy of the Rhine Graben, Bresse Graben and Molasse Basin: correlation of Alpine foreland events. Tectonophysics. 300, 249-284.

Skotnicki, S.J. Knauth, L.P., 2007. The middle Proterozoic Mescal paleokarst, central Arizona, USA: karst development, silicification, and cave deposits. Journal of Sedimentary Research. 77, 1046-1062.

Slagstad, T., Roberts, N.M.W., Marker, M., Røhr, T.S., Schiellerup, H., 2013. A non-collisional, accretionary Sveconorwegian orogen. Terra Nova. 25, 30-37.

Soegaard, K., Callahan, D.M., 1994. Late Middle Protero- zoic Hazel Formation near Van Horn, trans-Pecos Texas: Evidence for transpressive deformation in Grenvillian basement. Geological Society of America Bulletin. 106, 413423.

Spiegel, C., Kuhlemann, J., Dunkl, I., Frisch, W., Von Eynatten, H., Balogh, K., 2000. The erosion history of the Central Alps: evidence from zircon fission track data of the foreland basin sediments. Terra Nova. 12, 163-170.

Spencer, C.J., Prave, A.R., Cawood, P.A., Roberts, N.M.W., 2014. Detrital zircon geochronology of the Grenville/Llano foreland and basal Sauk Sequence in west Texas, USA: Geological Society of America Bulletin. 126, 1117-1128.

Spencer, C.J., Cawood, P.A., Hawkesworth, C.J., Prave, A.R., Roberts, N.M.W., Horstwood, M.S.A., Whitehouse, M. J., et al., 2015. Generation and preservation of continental crust in the Grenville Orogeny. Geoscience Frontiers. 6 , 357-372.

Stein, C.A., Kley, J., Stein, S., Hindle, D., Keller, G.R., 2015. North America's Midcontinent Rift: When rift met LIP. Geosphere. 11 (5), 1607-1616.

Stevenson, G. M., Beus, S. S. 1982. Stratigraphy and Depositional Setting of the Upper Precambrian Dox Formation in Grand-Canyon. Geological Society of America Bulletin. 93, 163-173.

Stewart, J.H., Gehrels, G.E., Barth, A.P., Link, P.K., Christie-Blick, N., Wrucke, C.T., 2001. Detrital zircon provenance of Mesoproterozoic to Cambrian arenites in the western United States and northwestern Mexico. Geological Society of America Bulletin. 113, 1343-1356.

Stewart, A.D., 2002. The later Proterozoic Torridonian rocks of Scotland: their sedimentology, geochemistry and origin. Geological Society Memoir, 24. The Geological Society, London.

Storey, C.D., Brewer, T.S., Temperly, S., 2005. P-T conditions of Grenville-age eclogite facies metamorphism and amphibolite facies retrogression of the Glenelg-Attadale Inlier, NW Scotland. Geological Magazine. 142, 605-615.

Thomann, W. F., 1980, Ignimbrites, trachytes, and sedimentaiy rocks of the Precambrian Thunderbird Group, 
Franklin Mountains, El Paso, Texas: Geological Society of America Bulletin. 92, 94-100.

Timmons, J.M., Karlstrom, K.E., Heizler, M.T., Bowring, S.A., Gehrels, G.E., Crossey, L.J., 2005. Tectonic inferences from the ca. 1255-1100 Ma Unkar Group and Nankoweap Formation, Grand Canyon: Intracratonic deformation and basin formation during protracted Grenville orogenesis. Geological Society of America Bulletin. 117, 15731595

Tohver, E., Teixeira, W., Van Der Pluijm, B., Geraldes, M. C., Bettencourt, J. S., Rizzotto, G., 2006. Restored transect across the exhumed Grenville orogen of Laurentia and Amazonia, with implications for crustal architecture. Geology. 34, 669-672.

Tollo, R.P., Corriveau, L., McLelland, J.M., Bartholomew, M.J., (Eds.), 2004. Proterozoic tectonic evolution of the Grenville orogen in North America: Geological Society of America Memoir 197. p. 820.

Tweto, O., 1983, Las Animas Formation (Upper Precambrian) in the Subsurface of Southeastern Colorado. U.S. Geological Survey Bulletin 1529-G. p. 20.

van Nostrand, T., Lowe, D., 2010. Geology of the Seal Lake area, central Labrador (parts of NTS map sheets $13 \mathrm{~K} / 3,4,5$ and 6). In Current Research, Newfoundland and Labrador Department of Natural Resources, Geological Survey, Report 10-1. 1-20.

Van Schmus, W.R., Bickford, M.E., Turek, E., 1996. Proterozoic geology of the east-central mid-continent basement. In van der Pluijm, B.A., Catacosinos, P.A., (Eds.), Basement and basins of eastern North America: Geological Society of America Special Paper 308. p. 7-32.

Walker, N., 1992. Middle Proterozoic geologic evolution of Llano Uplift, Texas : Evidence from U-Pb zircon geochronometry: Geological Society of America Bulletin. 104, 494-504.

Weil, A.B., Geissman, J.W., Heizler, M., Van der Voo, R., 2003. Paleomagnetism of Middle Proterozoic mafic intrusions and Upper Proterozoic (Nankoweap) red beds from the Lower Grand Canyon Supergroup, Arizona. Tectonophysics. 375, 199-220.

Weiss, G.C., 1986. A depositional analysis of the Arkose member (middle Proterozoic) of the Troy Quartzite in central Arizona. [M.S. thesis]. Flagstaff, Northern Arizona University. p. 382.

White, N.M., Pringle, M., Garzanti, E., Bickle, M., Najman, Y., Chapman, H., Friend, P., 2002. Constraints on the exhumation and erosion of the High Himalayan Slab, NW India, from foreland basin deposits. Earth Planetary Science Letters. 195, 29-44.

Whitmeyer, S.J., Karlstrom, K.E., 2007. Tectonic model for the Proterozoic growth of North America. Geosphere. 3(4), 220-259.

Williams, G.E., Foden, J., 2011. A unifying model for the Torridon Group (early Neoproterozoic), NW Scotland: Product of post-Grenvillian extensional collapse. Earth-Science Reviews. 108, 34-49.

Williams, M.L., 1991. Overview of Proterozoic metamorphism in Arizona, in Karlstrom, K.E., (Eds.), Proterozoic geology and ore deposits of Arizona: Arizona Geological Society Digest. 19, 11-26.

Wingate, M.T.D., Pisarevsky S.A., Evans, D.A.D., 2002. Rodinia connections between Australia and Laurentia: no SWEAT, no AUSWUS? Terra Nova. 14,121-128 
Wodicka, N., Parrish, R.R. Jamieson, R.A., 1996. The Parry Sound domain: a far travelled allochthon? New evidence from U-Pb zircon geochronology. Canadian Journal of Earth Sciences. 33, 1087-1104.

Wooden, J.L., Barth, A.P., Mueller, P.A., 2012. Crustal growth and tectonic evolution of the Mojave crustal province: insights from hafnium isotope systematics in zircons. Lithosphere. 5, 17-28.

Wooden, J.L., Stacey, J.S., Howard, K.A., Doe, B.R., Miller, D.M., 1988. Pb isotopic evidence for the formation of Proterozoic crust in the southwestern United States. In Ernst, W.G., (Eds.), Metamorphism and Crustal Evolution of the Western United States: Englewood Cliffs, New Jersey, Prentice-Hall. p. 68-86.

Wrucke, C.T., 1989. The middle Proterozoic Apache Group, Troy Quartzite, and associated diabase of Arizona. Arizona Geological Society Digest. 17, 239-258.

Wynne-Edwards, H.R., 1972. The Grenville Province. In Price, R.A., Douglas, R.J.W. (Eds.), Variations in Tectonic Styles in Canada. Geological association of Canada Special Paper 11. 263-334.

Yin, A., Harrison, T. M., 2000. Geologic evolution of the Himalayan-Tibetan orogn: Annual Reviews of Earth and Planetary Sciences. 29, 211-280. 


\section{Figure Captions}

Figure 1: Pre-Neoproterozoic geology of southwest Laurentia showing Archean to Mesoproterozoic basement terranes (after Whitmeyer \& Karlstrom, 2007), Late Mesoproterozoic fault trends and sedimentary basins (after Timmons et al., 2005), and magmatic rocks (after Bright et al., 2014). The Sr. 706 Line marks the western limit of Proterozoic crust in Laurentia. SG- San Gabriel-Eagle Mountains Anorthosite-Magnerite-Charnockite-Granite suite. M1- Mescalero 1 Well. Inset shows position of Laurentia within the North American continent (after Whitmeyer \& Karlstrom, 2007): Can.- Canada, U.S.- United States, Mex.- Mexico, S Grenville- southern Grenville orogen, NE Grenville- northeastern Grenville orogen.

Figure 2: Regional correlation of Late Mesoproterozoic sedimentary and magmatic rocks in southwest Laurentia and relationship to tectonic events in the Grenville orogen of southern Laurentia (modified from Timmons et al. (2005) with revised age of 1115-1066 Ma for Pike's Peak Granite from Guitrea et al. (2016), revised age of lower member of the Crystal Spring Formation from Mahon et al. (2014), age of Thunderbird Group from Bickford et al. (2000). Timing of tectonic events in Llano uplift (southern Grenville orogen) from Mosher et al. (2008). The ca. $1100 \mathrm{Ma}$ and $1250 \mathrm{Ma}$ magmatic rocks cross-cut older units so no age range is implied by the vertical orientation of the ca. $1100 \mathrm{Ma}$ and $1250 \mathrm{Ma}$ intrusive rocks in the diagram.

Figure 3: Idealised stratigraphic column of the Unkar Group, Grand Canyon, Arizona. The column is a composite of representative measured sections from each of the main depositional units and is compiled from: Dox Formation: Stevenson \& Beus (1982), Hakatai Shale: Reed (1976), Bass Formation: Timmons et al. (2005). The Shinumo Sandstone section was measured during this study. Stars show approximate stratigraphic location of detrital mineral samples collected or compiled for this study, star labels correspond to sample numbers listed in Supplementary File 1. Field photographs show typical lithologies and sedimentary features of the Unkar Group: A) Ripple marks in fine-grained red sandstone, Dox Formation. B) Convoluted folds in quartz arenite produced by soft sediment deformation, Shinumo Sandstone. C) Unconformity between Shinumo Sandstone and Hakatai Shale. D) mudcrack casts in red mudstone, Hakatai Shale. E) Stromatolitic dolomite, Bass Formation. F) Polymictic conglomerate, Hotauta Member of Bass Formation. Inset shows paleocurrent data summarised in rose diagrams with bin widths of $10^{\circ}$. Paleocurrent data compiled from: Dox Formation: Stevenson \& Beus (1982), Timmons et al. (2005), Shinumo Sandstone: Timmons et al. (2005), Hakatai Shale: Reed (1976).

Figure 4: Probability distribution plots of detrital zircon and detrital muscovite data from Late Mesoproterozoic sequences of southwest Laurentia. Coloured bars show age range of tectonic events in the southern Grenville Orogeny (after Mosher et al., 2008) and age ranges for basement provinces of southwest Laurentia. Inset map shows approximate location of samples (red stars) for each of the basins.

Figure 5: Probability distribution plots and histograms of the young populations (1350-1100 Ma) of detrital zircon, muscovite, and biotite ages from Late Mesoproterozoic basins of southwest Laurentia. Detrital zircon age peaks were derived from Unmix algorithm of Isoplot (Table 1). Coloured bars show age ranges for tectonic events in the southern Grenville Orogeny (after Mosher et al., 2008).

Figure 6: Tectonic evolution of southwest Laurentia from $1255 \mathrm{Ma}$ to $1070 \mathrm{Ma}$ highlighting the relationship between tectonic events in the Grenville orogen and intracratonic sedimentary basins. Symbols and colours for basement terranes, faults, and magmatic rocks as for Figure 1. Blue arrows show approximate sedimentary dispersal patterns based on provenance and paleocurrent data (see text for details). Insets show schematic southeast-northwest trending cross sections through Grenville orogen and intracratonic basins: A) 1255-1230 Ma: retroarc basin formation, accommodation space created by coupling of convecting mantle above subduction zone and upper plate (cartoon modified from DeCelles, 2012), sediments sourced from local basement and continental margin arc. B) 1230-1180: slab break off, uplift of 1255-1230 Ma carbonate sequences, subduction zone reversal, mafic underplating leads to emplacement of Anorthosite-Magnerite- 
Charnockite-Granite suites in California. C) 1140-1100 Ma: Foreland basin sedimentation during early stages of continent-continent collision in Llano uplift (central Texas), regional northeastsouthwest directed extension, accommodation space produced by loading of upper plate by thrust nappes, sediments sourced from local basement and structurally high parts of Grenville orogen. Subduction continues in western Texas leading to clockwise rotation of colliding continent (Davis \& Mosher, 2015). D) 1100-980 Ma: post-collisional magmatism and uplift in the Llano uplift, 11501050 Ma mafic magmatism throughout southwest Laurentia. Continent-continent collision in western Texas at 1060-980 Ma. Proximal foreland basin sedimentation in Hazel Formation at 1060-1035 $\mathrm{Ma}$, cross section of collisional orogen modified from Garzanti et al. (2004; for the Alps). 

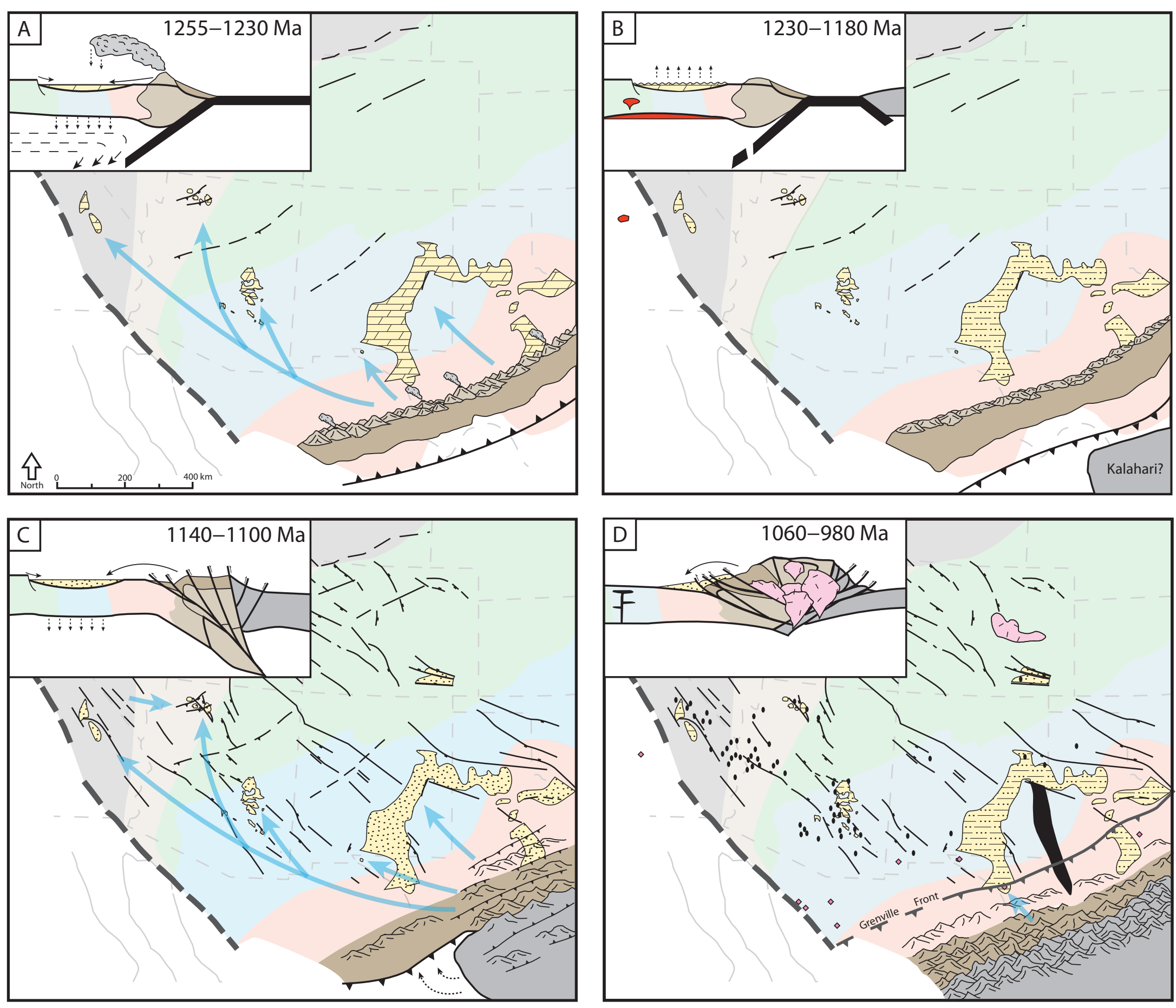
Figure 5
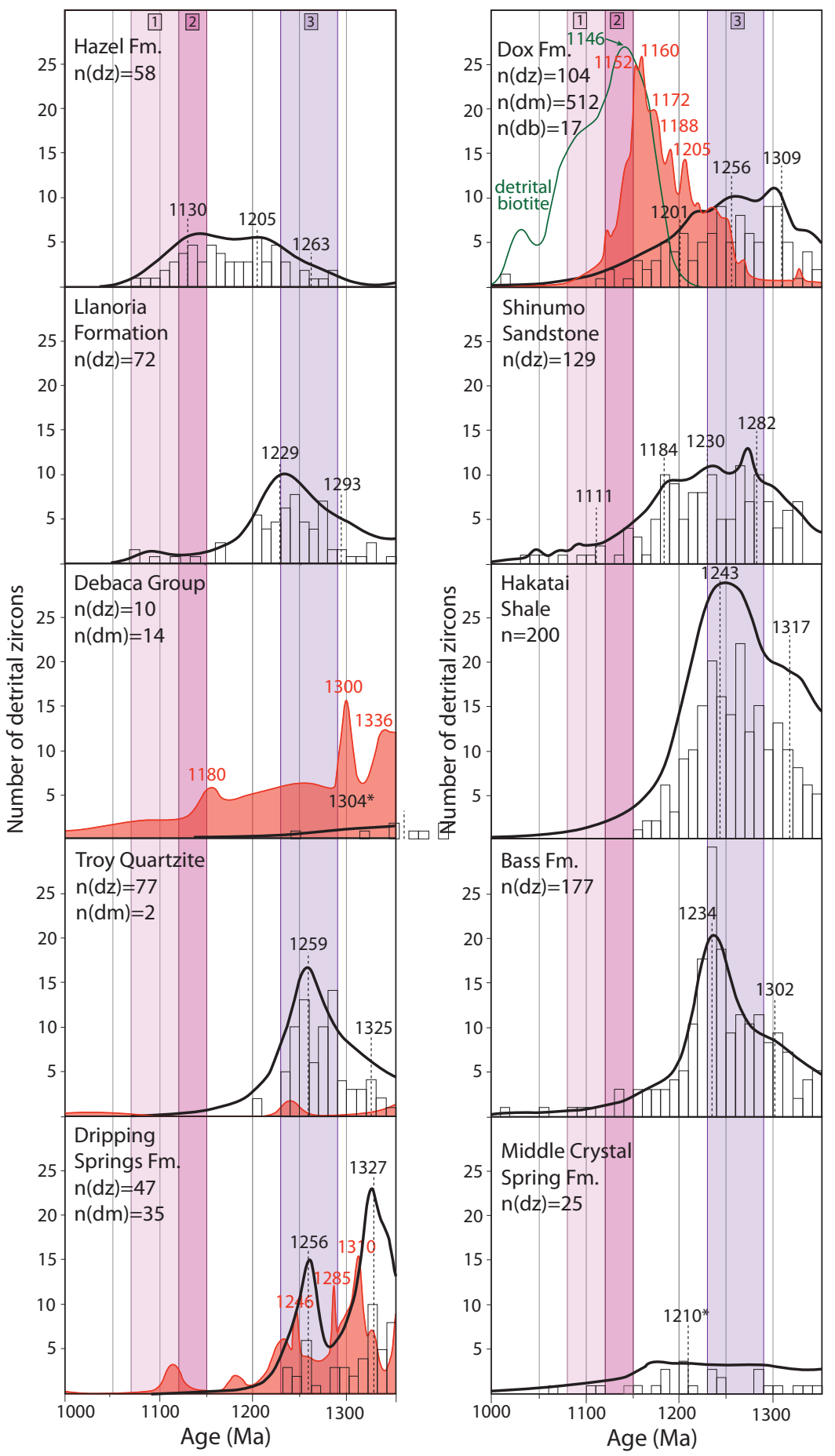

Detrital Spectra

$\bigwedge$ Zircon $\left({ }^{207} \mathrm{~Pb} /{ }^{206} \mathrm{~Pb}\right.$ Age $) \quad \bigwedge$ Muscovite $\left({ }^{40} \mathrm{Ar} /{ }^{39} \mathrm{Ar}\right.$ Age $)$

$\mathrm{dz}=$ detrital zircon, $\mathrm{dm}=$ detrtial muscovite, $\mathrm{db}=$ detrital biotie

Grenville Events

1 Post-collisional magmatism 1120-1070 Ma

2 Continent-continent collision 1150-1120 Ma

3 Continental arc magmatism 1288-1232 Ma 


\section{Figure 4}

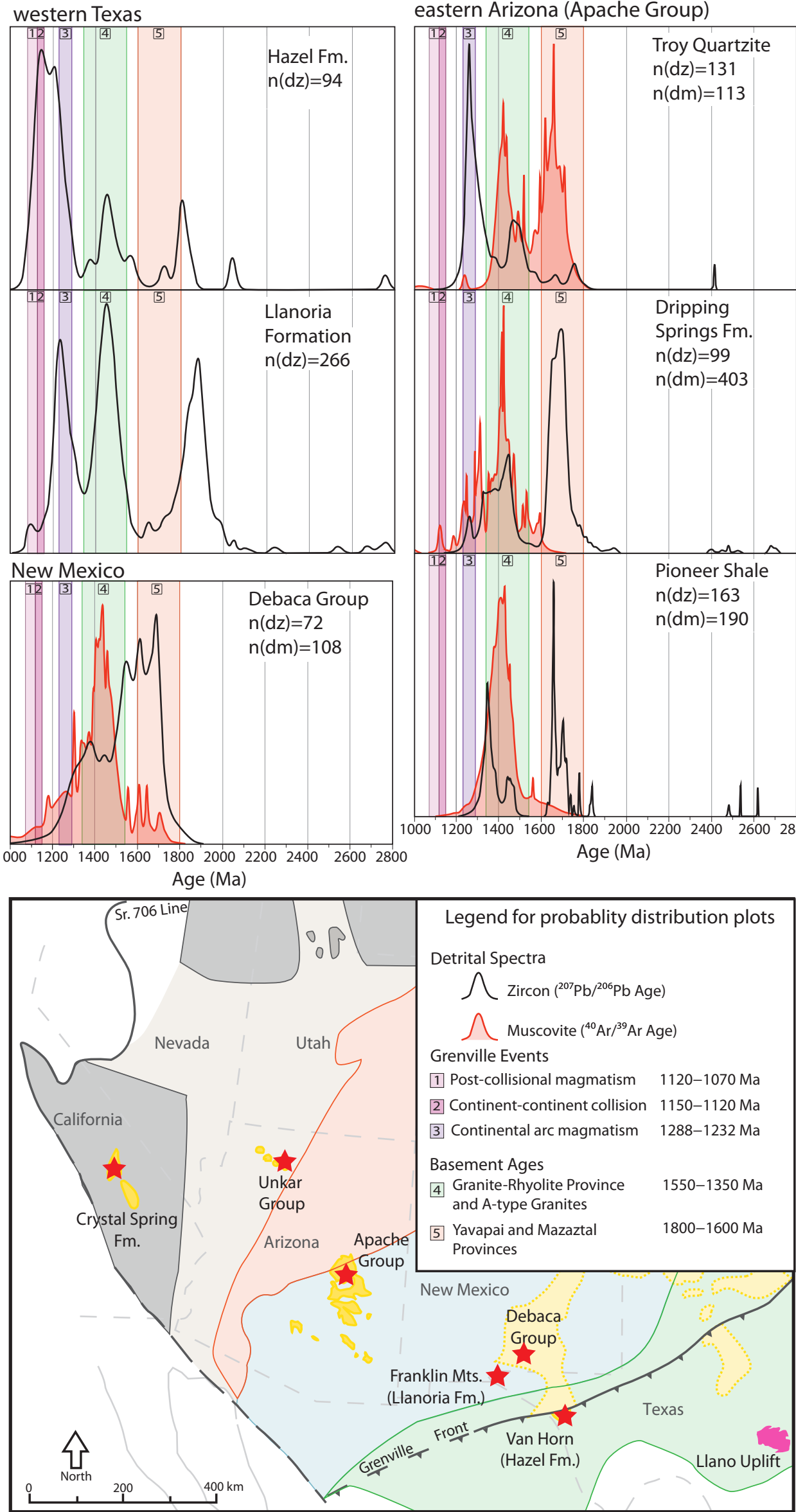

Grand Canyon (Unkar Group)

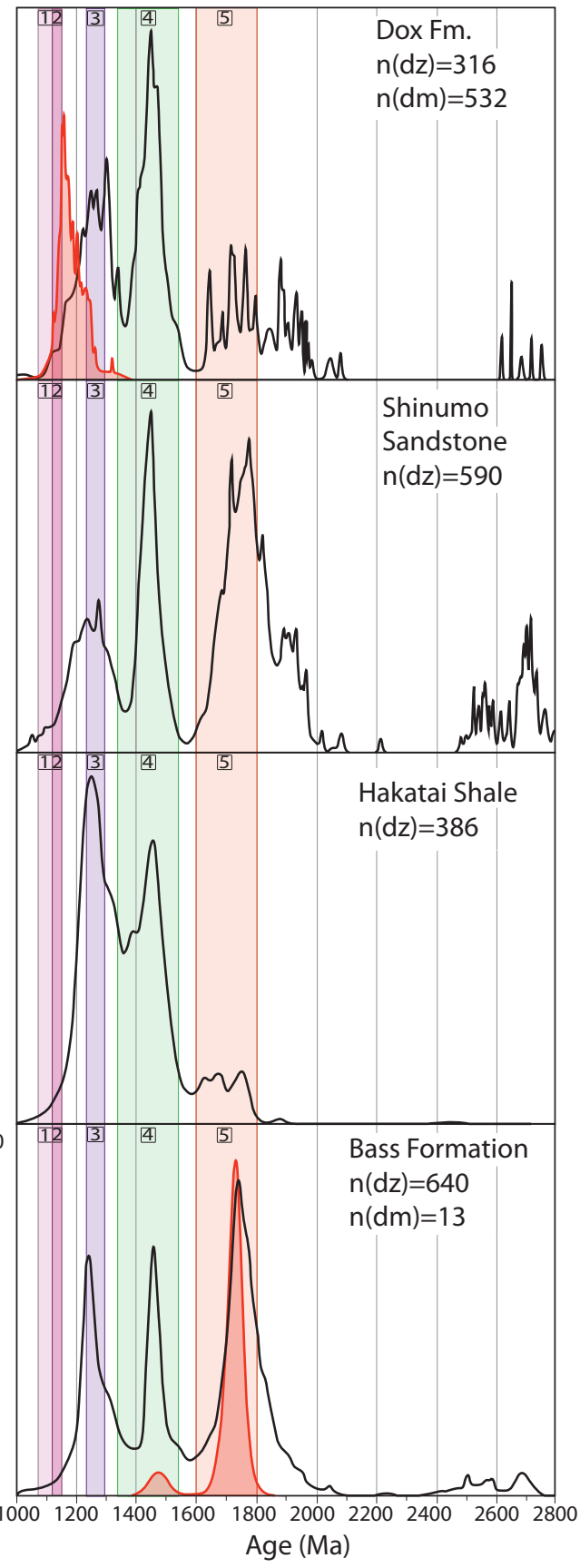

Death Valley (Crystal Spring Fm.)

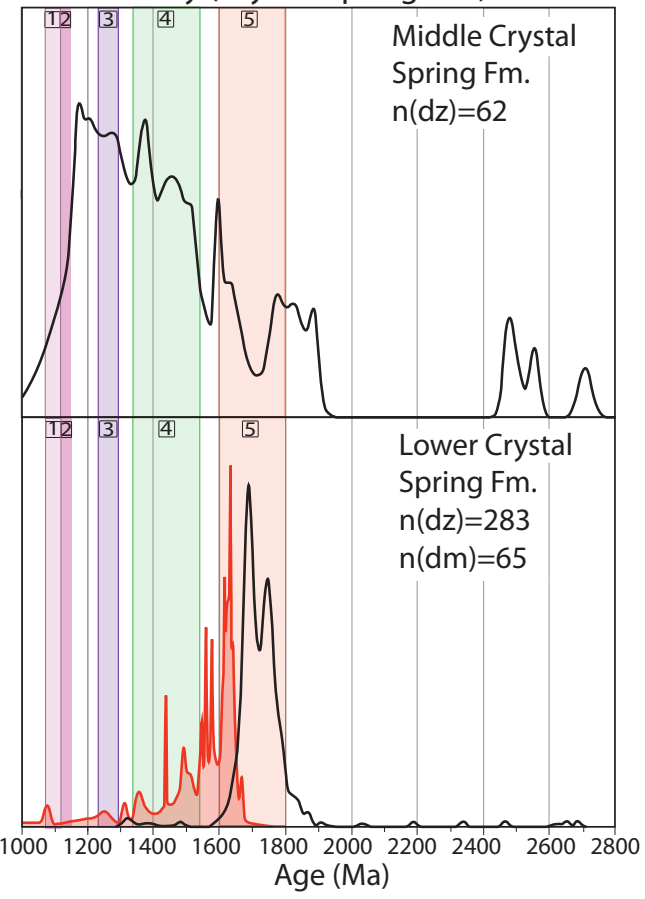




\section{Figure 3}

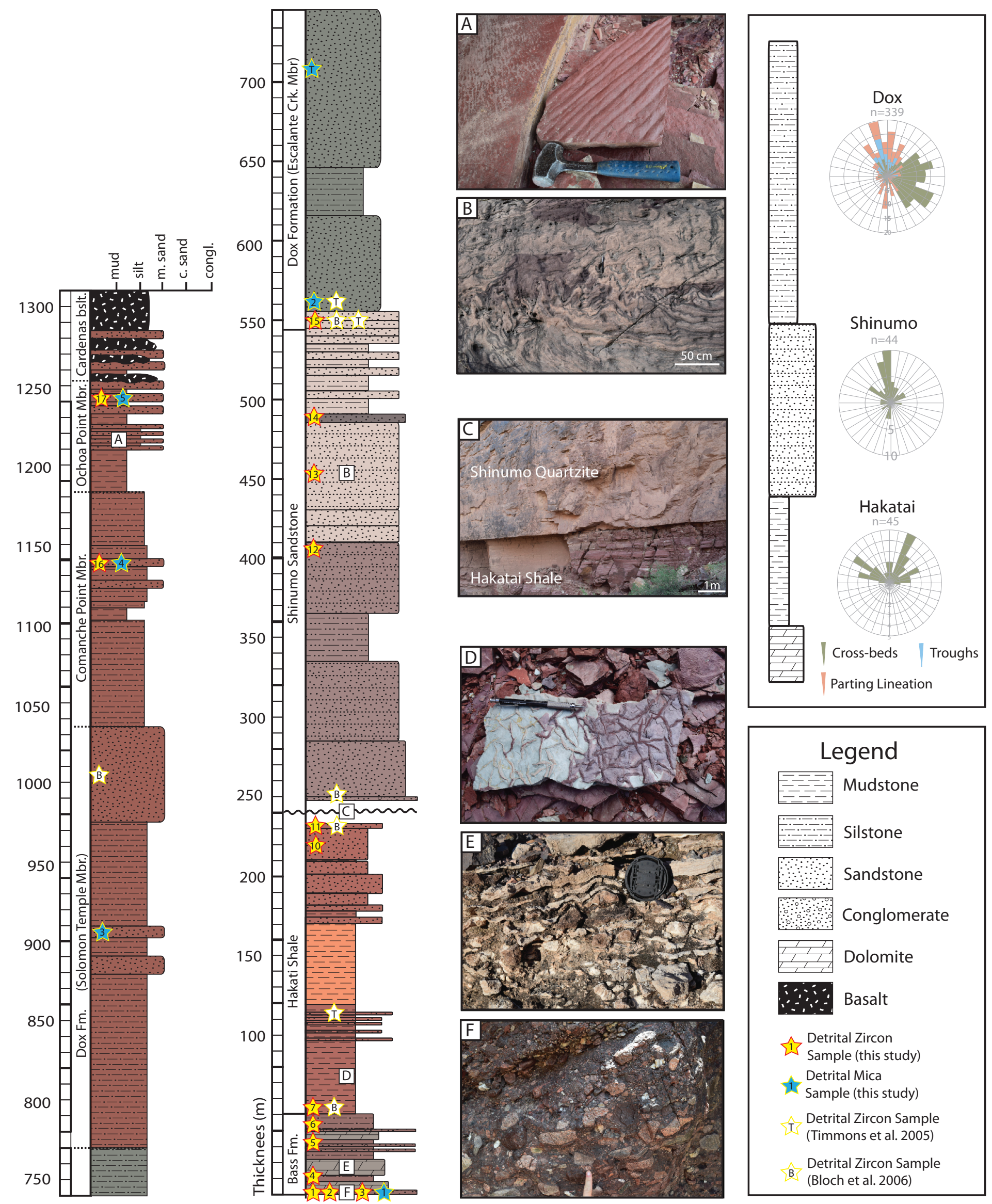




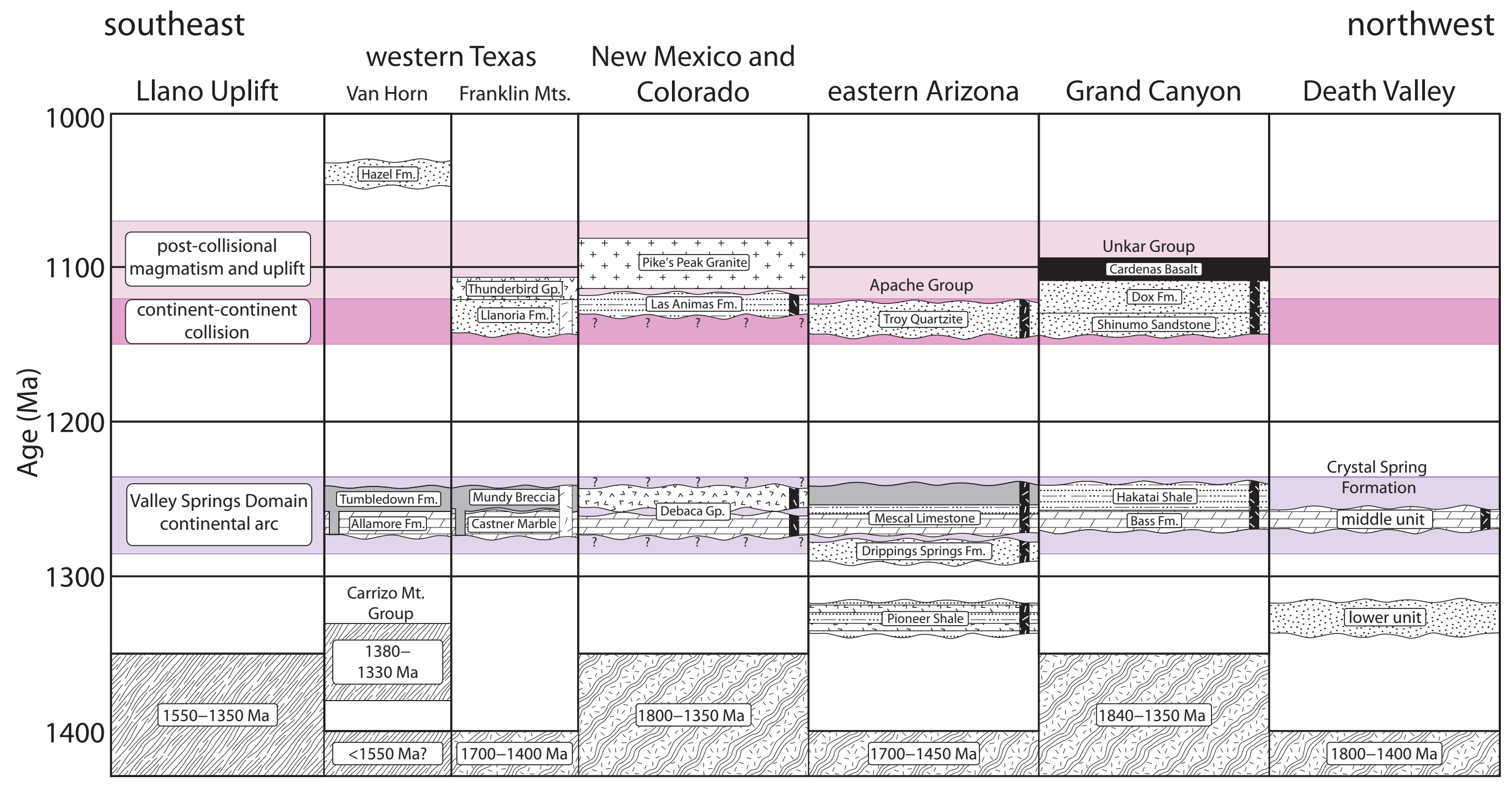

\section{Legend}
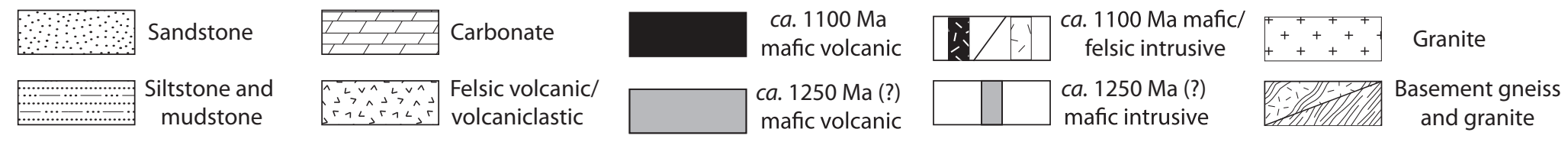


\section{Figure 1}

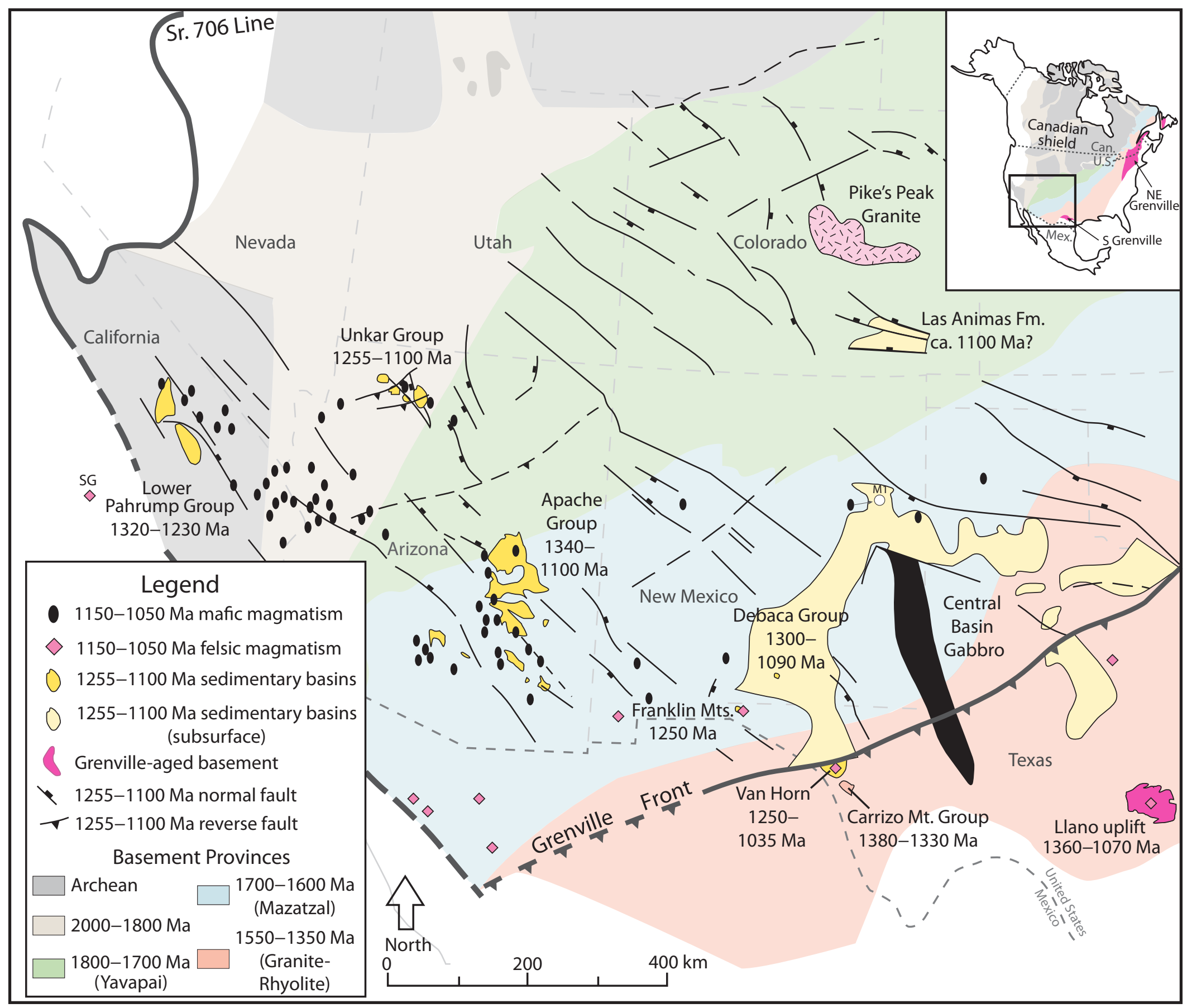

